\title{
A COMPARISON OF THE MINERALOGY OF SRI LANKA AND A PART OF EAST ANTARCTICA.
}

SARATH JAYATILEKE

Minerals Technology Section, C.I.S.I.R., P.O.Box 787, Colombo.

AND

HIROHARU MATSUEDA

Department of Geology and Mineralogy, Faculty of Science, Hokkaido University, Sapporo 060, Japan.

(Date of receipt : 12 March 1992)

(Date of acceptance : 28 September 1992)

\begin{abstract}
This paper presents the mineralogical data from marble and skarns of Sri Lanka and compares them with those of Lutzow Holm Bay - Prince Olav Coast Enderby Land in East Antarctica. Impure marble and skarn oeposits in this part of East Antarctica and Sri Lanka contain abundant phlogopite, forsterite, apatite, spinel. Calcite-dolomite exsolution texture is clearly displayed in all samples and the equilibrium temperatures for exsolutions have been estimated. Some of the spinels both in Sri Lanka and East Antarctica are zincian. Uvite ( $\mathrm{Ca}$ - tourmaline), which is rarè in nature, has been reported from both Sri Lanka and East Antarctica. Sapphirine observed in skarns of Sri Lanka is associated with relatively low grade minerals such as phlogopite and serpentine. This may represent retrograde metamorphism. But sapphirine-quartz in direct contact, which suggests high temperatures, is also occasionally observed. Sapphirine also is associated with kornerupine and orthopyroxene (bronzite) in Sri Lanka. Occurrences of quartz-free sapphirine bearing lithologies in Lutzow Holm Bay and Prince Olav Coast were reported recently. Sapphirine-quartz assemblages are well developed in granulite facies rocks in the Napier Complex of East Antarctica. Beryl and alkali feldspar (perthitic or antiperthitic) occur in pegmatites both in Sri Lanka and East Antarctica. Mineralogical and geological features observed by the present authors and earlier workers in Sri Lanka match those of Lutzow Holm Bay and Prince Olav Coast in East Antarctica. These findings support the juxtaposition of the above mentioned regions as part of a Gondwanaland paleo continent reconstruction.
\end{abstract}

\section{INTRODUCTION}

Study of the regional tectonics and plate tectonic models, during the last few decades, has helped to reconstruct the Gondwanaland continent. According to some of these Gondwanaland maps, ${ }^{1}$ Sri Lanka is placed near the Prince Olav Coast of East Antarctica, but the exact position of Sri Lanka has not been firmly established. Until very recently, Sri Lanka has not been of much interest with regards to the reconstruction of Gondwanaland.

According to recent studies ${ }^{2}$ the high grade metamorphic rocks of Sri Lanka are not dissimilar to those of parts of India and East Antarctica. Findings of gem minerals 
such as the blue corundum (sapphire) and spinel in skarn and gneisses from East Antarctica, ${ }^{3}$ generated interest in the metamorphic rock facies of Sri Lanka and India, since these countries are well known for many kinds of gems.

The purpose of this study is to understand the geological and mineralogical similarities between Sri Lanka and part of East Antarctica with particular reference to the mineralogy of marble, skarn and gneisses. The Antarctica specimens used in this study were collected by one of us (H.M.) during the 23rd Japanese Antarctic Research Expedition (JARE) in 1981 - 1982.

\section{OUTLINE OF GEOLOGY IN SRI LANKA AND EAST ANTARCTICA}

\section{Sri Lanka}

Most of the surface area (about 90\%) of Sri Lanka consists of non-fossiliferous Precambrian metamorphic rocks which are subdivided into the Highland/Southwestern Complex, the Vijayan Complex and the Wanni Coplex. ${ }^{4}$ Subsidiary Jurasssic, Miocene, Pleistocene and Recent sedimentary formations also occur (Figure 1).

\section{(a) Highland/Southwestem Complex (HSWC)}

Major rock types are as listed in Table 1. Granulite facies rocks are characterized by mainly perthitic potassium feldspar, antiperthitic plagioclase, pyrope-almandine garnet and rutile. Other constituents are hyperthene, diopside, sillimanite, scapolite, hornblende, biotite, cordierite, calcite, dolomite, forsterite, wollastonite, spinel, phlogopite and sphene. ${ }^{5}$ Some of these rocks were derived from an Archean source but the majority were early Proterozoic in age. ${ }^{6}$ It should be noted that basin like synformal structures known as "arenas" consisting of Vijayan type rocks within the HSWC are found in the Kandy area. ${ }^{2}$ In the Southwestern area charnockites and gneisses occur in alternating zones of varying width.

(b) Vijayan Complex (VC)

The most common rocks are as listed in Table 1 . Gneisses are characterized by the presence of lower metamorphic grade minerals such as hornblende and biotite compared to HSWC rocks. The boundary between the Highland/Southwestern Complex and Vijayan Complex shows a transitional zone containing both types of rocks and scattered serpentinite. This is also interpreted as a ductile thrust along which the HSWC rocks were transported Southeastward over the Vijayan Complex. According to the geochronological data available, Vijayan rocks are younger than HSWC rocks. Before 1991 this was referred to as East Vijayan Complex. 


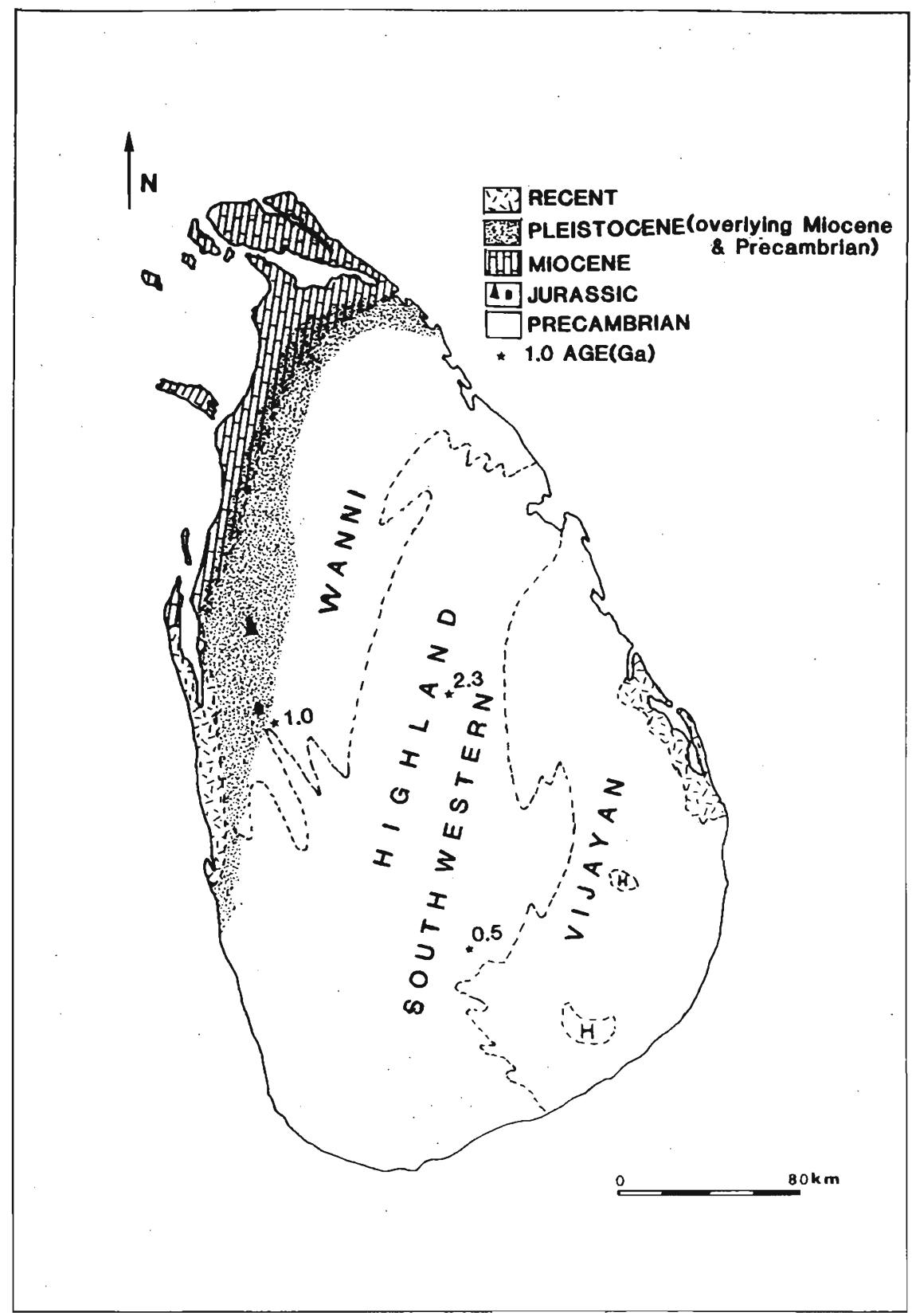

Figure 1: Geological formations on Sri Lanka. ${ }^{27}$ 
Table 1: Rock types in Sri Lanka

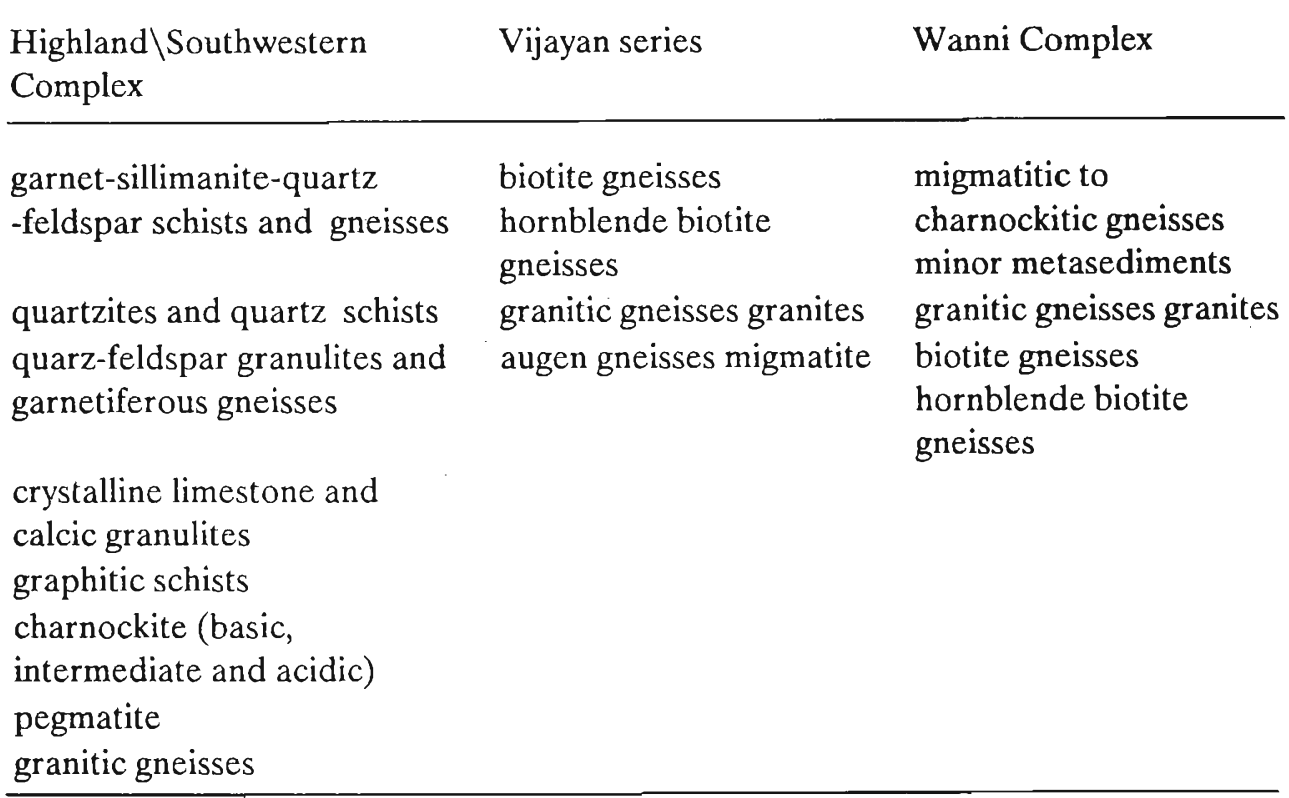

\section{(c) Wanni Complex}

Before 1991 this was referred to as the "West Vijayan Complex". ${ }^{7}$ Granitoid gneisses, charnockitic gneisses are the most common rock types. ${ }^{4}$ The geochronological data of these rocks are similar to that of Vijayan rocks. The boundary between the Wanni Complex and the HSWC is not clear. Voll and Kleinschrodt ${ }^{8}$ reject the establishment of a Wanni Complex considering the data insufficient to establish an independent lithological and structural unit:

The comparatively limited Jurassic rocks (Figure 1) consist mainly of feldspathic or arkosic sand stone, siltstone and calcareous shales.

In addition to limestone of Miocene age in the northern area (Figure 1), small occurrences of Miocene beds containing limestone grit and sandstone are also found in the south coast. ${ }^{7}$

Pleistocene formations overlie part of the Miocene and Precambrian rocks of the island. They consist mainly of laterite and red earths.

Recent residual and alluvial deposits contain kaolin, ball clay, gem gravel, coral etc..

Dolerite dykes occur in the Eastern province. ${ }^{9}$ 


\section{East Antarctica}

In Enderby land of East Antarctica, the Napier Complex consists of high grade granilite facies rocks; the Rayner Complex manifests the amphibolite facies (Figure 2). The boundary between these facies is not clear. It has been suggested that the Rayner Complex, with the age of $0.8-1.1 \mathrm{Ga}$ (i.e. Proterozoic) was formed by remetamorphism of the Archean Napier Complex. ${ }^{10}$

The Lutzow Holm Bay region consists mainly of granulite facies rocks; the adjoining Prince Olav Coast terrain is transitional between amphibolite and granulite facies. ${ }^{11}$ The predominant rock types in Lutzow Holm Bay are pyroxene gneisses and garnet gneisses. Other rock types present are ultrabasic and basic granulites, marble and quartzite. ${ }^{12}$

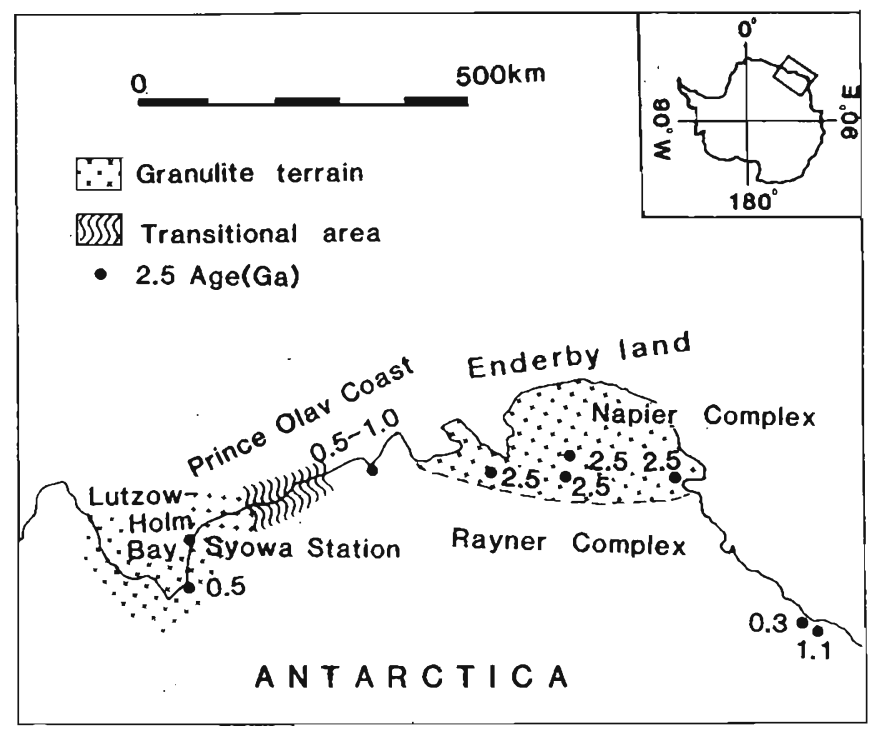

Figure 2: Distribution of rock types and geochronological data around Lutzow Holm Bay, Prince Olav Coast and Napier Complex.

Mode of occurrence of minerals

Mode of occurrence of the studied minerals is briefly described below.

\section{Sri Lanka}

(a) Marble and skarn (type) deposits

(i) Sample No. 9 (Kaludewela, Matale - Rattota Road)

The presence of the sky blue apatite crystals ranging upto about $7 \mathrm{~mm}$, is a characteristic feature of this deposit. Phlogopite is very rare. Calcite - dolomite exsolution texture is observed. Mineral assemblage and the chemical compositions of 
these species are shown in Tables 2,5 and 7. This deposit could have originated by the metamorphism of nearly pure dolomitic limestone.

Table 2: Mineral assemblages observed in marble and skarns from Sri Lanka

I. Sample No. 9 (Kaludewala, Matale - Rattota Rd.)

(a) Marble

1. Dol - Cc - Ap - Fo - Ser

2. Dol - Cc - Ap - Py

3. Dol - $\mathrm{Cc}-\mathrm{Phl}(-\mathrm{Gr})$

4. Dol - Cc- Par - Sph

II. Sample No. 10 (Waturawanguwa, Kandy - Rupaha Rd.)

(a) Impure marble (No. 10A)

1. Dol - Cc - Pl - Phl (-Py)

2. Dol - $\mathrm{Cc}-\mathrm{Phl}-\mathrm{Sp}(-\mathrm{Gr})$

3. Dol - Cc- Phl - Fo - Ser

4. Dol - Cc - Cpx - Pl

(b) Skarn (No. 10B)

1. $\mathrm{Phl} \cdot \mathrm{Cc}(-\mathrm{Dol})$

2. $\mathrm{Phl}-\mathrm{Cc}(-\mathrm{Dol})-\mathrm{Ap}$

III. Sample No. 11 (Ampitiya - Kandy)

(a) Marble (No. 11A)

1. Dol - Cc

2. Dol - $\mathrm{Cc}-\mathrm{Fo}$

3. Dol - Cc - Pl

(b) Skarn (No. 11B)

1. $\mathrm{Par}-\mathrm{Sp}-\mathrm{Phl}-\mathrm{Cc}-\mathrm{Dol}(-\mathrm{Pl})$

2. $\mathrm{Par}-\mathrm{Sp}-\mathrm{Phl}-\mathrm{Cc}-\mathrm{Tou}$

(c) Skarn (No. 11C)

1. $\mathrm{Sa}-\mathrm{Sp}-\mathrm{Phl}$

2. Sa - Qtz - Sp - Ser - Par

3. Sa-Sp-Par-Ser

4. Sa - Phl - Py - Ser

5. $\mathrm{Sa}-\mathrm{Par}-\mathrm{Py}-\mathrm{Cc}$

6. $\mathrm{Sa}-\mathrm{Phl}-\mathrm{Pl}$

7. Sa-Par - Dol - Ser

8. Sp - Par - Ser

9. Sa-Kor - Opx

(d) Skarn (11D)

1. $\mathrm{Sp}-\mathrm{Cpx}-\mathrm{Cc}-\mathrm{Py}$

2. $\mathrm{Sp}-\mathrm{Qtz}-\mathrm{Py}-\mathrm{Pl}$

(There is a narrow reaction rim, $\mathrm{Fe}-\mathrm{Mg}$ - $\mathrm{Al}$ silicate, between $\mathrm{Sp}$ and Qtz.)

Abbreviations: Al Px - fassaitic pyroxene, Amp - amphibole, An - anorthite, Anal - analcime, Bio - biotite, $\mathrm{Cc}$ - calcite, Cord - cordierite, Cpx - clinopyroxene, $\mathrm{Cr}$ - corundum, Dol - dolomite, Fo - forsterite, Gar garnet, Gr - graphite, Kf - K- feldspar, Korn - komerupine, Opx - orthopyroxene, Os - osumilite, Par pargasite, Phl - phlogopite, Pl - plagioclase, Py - pyrite, Qtz - quartz, Sa - sapphirine, Scap - scapolite, Ser serpentine, Sill - sillimanite, Sp - spinel, Sph - sphene, Tou - tourmaline. 
Table 3 : Skarn types and their mineral assemblages, from Skallevikhalsen, East Antarctia $^{3}$

(A) In màrble

(i) Impure marble (recrystallized)
(a) Fo- Sp*
(b) $\mathrm{Sp}-\mathrm{Phl}^{*}$
(c) $\mathrm{Cpx}-\mathrm{Fo}$
(d) $\mathrm{Ap}-\mathrm{Di}(-\mathrm{Phl})^{*}$

* Graphite bearing

(ii) Nodule - like
(a) Phl - Scap (-Sp - Cr)
(b) $\mathrm{Phl}-\mathrm{Sp}$
(c) Phl - Amp (-Sp)
(d) Phl - Tour - Anal (-Scap)
(e) $\mathrm{Phl}-\mathrm{An}$

(B) Marble - gneiss contact

(i) Massive green pyroxene skarn

(a) Cpx (-Amp-Phl - Scap)

(ii) Banded skarn
(a) Dol marble - Fo marble - Phl - Sp
Skarn - Al Px-Sp-Scap skarn - Qtz Gneisses
(b) Phl-Sp marble - Phl-Cpx skarn - Scap-Cpx skarn - Gar-Bio gneiss

(C) Veinlets

(i) In marble ... Al Px - Phl - Amp - Pl

(ii) In green pyroxene skarn ... Phl (-Pl - Qtz)

(iii) In pale green pyroxene skarn ... Amp - Cc

Abbreviations are as in Table 2.

(ii) Sample No. 10 (Waturawanguwa, Kandy - Rupaha Road)

This is from a recrystallized impure marble deposit. Amber coloured skarn veinlets of phlogopite 20 to $30 \mathrm{~cm}$ in thickness are abundant in some parts.

Major minerals present in this dolomite marble deposit are dolomite, phlogopite, plagioclase, pargasitic amphibole, salitic pyroxene, spinel etc. as summarized in Table 2. Chemical compositions of these species are shown in Tables 5, 7,8 and 11. This sample also displays calcite-dolomite exsolution textures. 
Table 4: Mineral assemblages in the sapphirine-bearing granulite from Mt. Riiser-Larsen (after Motoyoshi and Matsueda) ${ }^{25}$

\begin{tabular}{ll} 
1. & Sa - Qtz \\
2. & Sa - Opx - Qtz - Pl - Kf \\
3. & $\mathrm{Sa}-\mathrm{Opx}-\mathrm{Sill}-\mathrm{Qtz}$ \\
4. & $\mathrm{Sa}-\mathrm{Opx}-\mathrm{Gar}$ \\
5. & $\mathrm{Sa}-\mathrm{Os}-$ Cord - Kf \\
6. & $\mathrm{Sa}$ - Os - Cord - Kf - Oppx \\
\hline
\end{tabular}

Abbreviations are as in Table 2.

Table 5 : Chemical composition of calcite and dolomite (Sri Lanka) by EPMA and calculated equilibrium temperature for co-existing calcite and dolomite.

\begin{tabular}{lccccccc}
\hline & $\mathrm{Cc}$ & $\mathrm{Dol}$ & $\mathrm{Cc}$ & $\mathrm{Cc}$ & $\mathrm{Dol}$ & $\mathrm{Cc}$ & Dol \\
\hline \multicolumn{1}{c}{ No. } & 9 & 9 & $10 \mathrm{~A}$ & $10 \mathrm{~A}$ & $10 \mathrm{~A}$ & $11 \mathrm{~A}$ & $11 \mathrm{~A}$ \\
\hline $\mathrm{MgO}$ & 04.08 & 20.10 & 01.89 & 03.37 & 20.37 & 03.21 & 20.19 \\
$\mathrm{CaO}$ & 49.62 & 34.14 & 52.95 & 50.04 & 31.54 & 00.08 & 31.70 \\
$\mathrm{FeO}$ & 00.08 & 00.07 & 00.17 & 00.20 & 00.19 & 54.52 & 00.07 \\
$\mathrm{MnO}$ & 00.00 & 00.02 & 00.06 & 00.07 & 00.01 & 00.07 & 00.04 \\
\hline $\mathrm{Total}$ & 53.78 & 54.33 & 55.07 & 53.68 & 52.11 & 57.88 & 52.00 \\
\hline $\mathrm{T}\left({ }^{0} \mathrm{C}\right)$ & 670 & & 519 & 628 & & 606 & \\
\hline $\mathrm{MgCO}_{3}$ & 08.33 & 42.37 & 03.84 & 06.88 & 43.08 & 06.61 & 42.72 \\
$\mathrm{CaCO}_{3}$ & 88.71 & 57.64 & 94.85 & 89.53 & 55.73 & 97.18 & 56.01 \\
$\mathrm{FeCO}_{3}$ & 00.13 & 00.12 & 00.27 & 00.32 & 00.30 & 00.19 & 00.11 \\
$\mathrm{MnCO}_{3}$ & 00.00 & 00.04 & 00.09 & 00.10 & 00.02 & 00.12 & 00.07 \\
$\mathrm{Total}$ & 97.17 & 100.17 & 99.05 & 96.84 & 99.13 & 104.09 & 98.90 \\
\hline
\end{tabular}

Carbonates were calculated by the Bence and Albce ${ }^{13}$ method.

$\mathrm{T}\left({ }^{0} \mathrm{C}\right)$ : Equilibrium temperature for co-existing calcite and dolomite, based on Rice. ${ }^{14}$

(iii) Sample No.11 (Ampitiya, Kandy)

Elongated nodule-like skarns up to several meters in length are located within the nearly pure dolomitic marble deposits. Constituent minerals are listed in Table 2. Typical mode of occurrence is shown in Plate 1(a). Spinel and pargasite are dominant 
minerals in some skarns whereas others are characterized by the presence of sapphirine, phlogopite and large crystals of pyrite which range up to about $2 \mathrm{~cm}$. Chemical compositions of those constituents are given in Tables 5,7,8,9,11 and 12 . These nodule-like skarns possibly originated by metamorphism of silicate impurities within the limestone.

\section{(b) Gems}

Studied gems were obtained from aluvial deposits from Sri Lanka. These gems were originally constituents of the surrounding metamorphic and/or pegmatitic country rocks and were deposited in the valleys after transportation by water from weathered surfaces.

\section{East Antarctica}

Marbles and skarns in Lutzow Holm Bay

Nodule-like skarns, ranging from $20 \mathrm{~cm}$ up to several meters in diameter, occur in pure marble. Matsueda et al. ${ }^{3}$ summarized the mineral assemblages of these as shown in Table 3. Spinel and scapolite are dominant phases. Mineral zonations are concentric and it is considered that they possibly originated from the interaction of gneissic rock fragments with dolomitic limestone host.

Zincian spinel and aluminous pyroxene are characteristic minerals near marble gneiss contacts. It is suggested that they originated from sources relatively high in alumina such as lateritic materials. ${ }^{3}$

In addition, there are veinlets, some of which cut across the above mentioned skarns and which are thus likely to have been formed after the main metamorphism, during which the nodule like skarns developed. ${ }^{3}$

\section{Mineralogy}

Representative minerals of marble and skarn deposits both from Sri Lanka and East Antarctica are described here. The analytical data presented in this paper were obtained from electron probe micro analysis (EPMA) and from X-ray powder diffraction patterns. EPMA was done using $15 \mathrm{kV}$ of accelerating voltages at Akita University and corrections were made according to Bence and Albee. ${ }^{13}$

\section{(1) Carbonate Minerals}

The most interesting charateristic feature is the presence of calcite-dolomite exsolution texture in all skarn and impure dolomites from Sri Lanka and East Antarctica. Equilibrium temperatures calculated using equation of ${ }^{14}$

$$
\log X^{C c}=\left(-1690 / T^{o} k\right)+0.795
$$


for calcite-dolomite exsolution are shown in Tables $5 \& 6$. They range from $519^{\circ}$ to $670^{\circ} \mathrm{C}$. Plate 1 (c) shows the calcite-dolomite exsolution texture for a Sri Lankan sample.

(a)

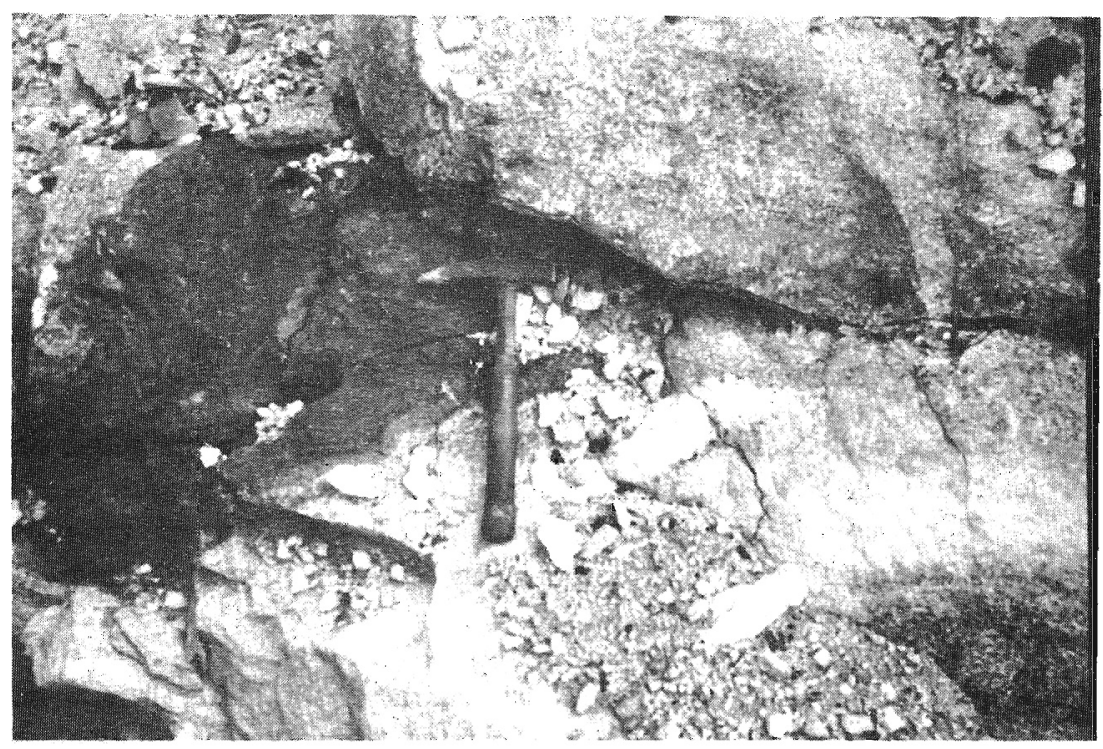

(b)
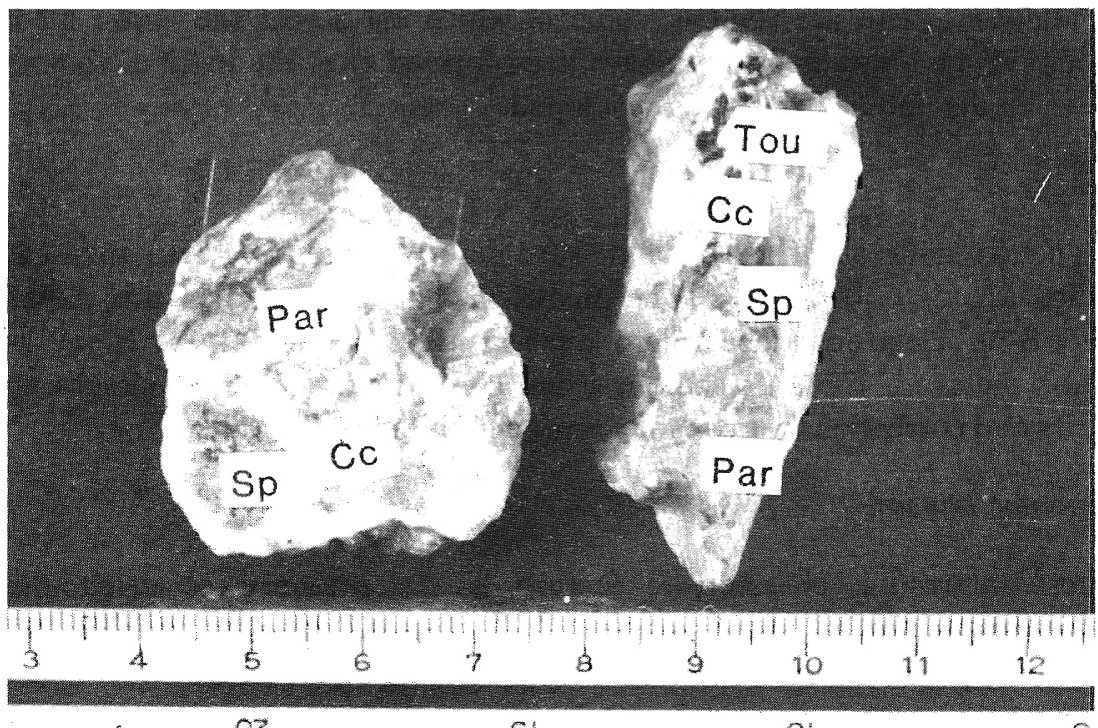

$a 2$

G!

ni 


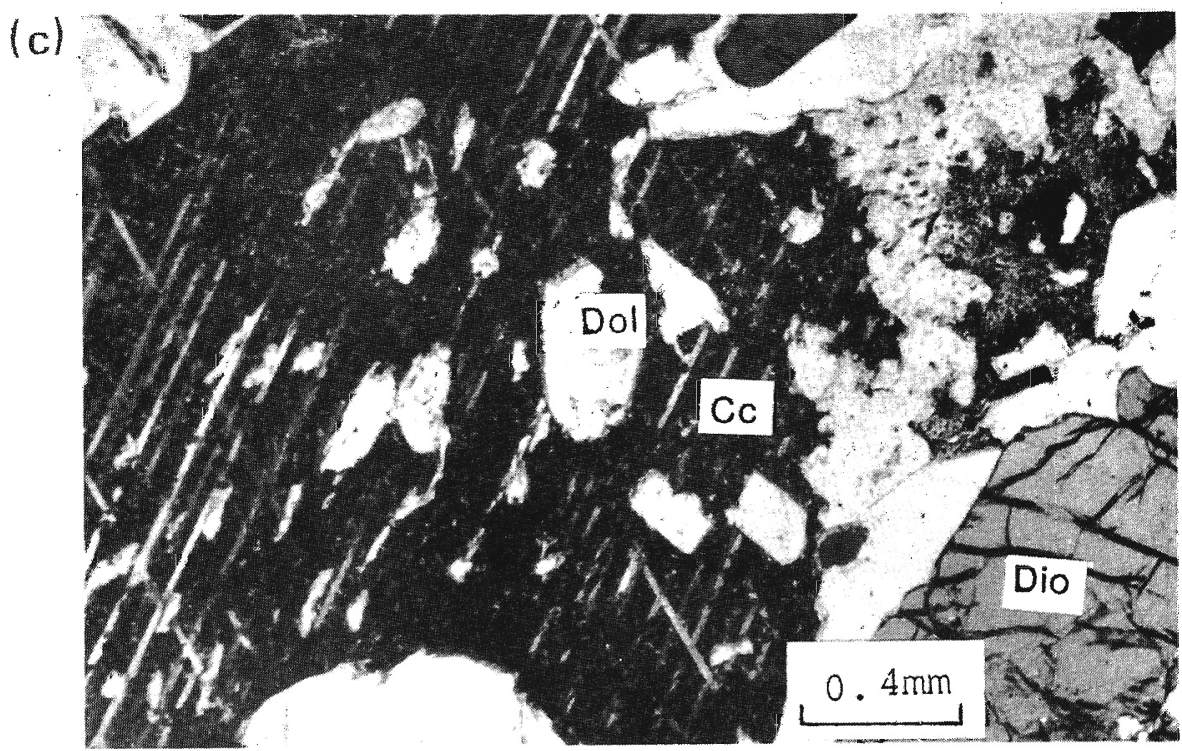

Plate 1: (a) Outcrop of Nodule-like skarn from Sri Lanka (Ampitiya, Kandy).

(b) Minerals in skarn from Ampiliya, Kandy. Par: pargasite, Sp: spinel, Cc: calcite, Tou: tourmaline (uvite).

(c) Calcite (Cc)-dolomite (Dol) exsolution texture under the microscope (crossed nicols) from Waturawanguwa, Kandy - Rupaha Rd., Sri Lanka. Dio: dlopside.

Table 6: Chemical composition of calcite (Antarctica) by EPMA and calculated equilibrrium temperature for co-existing calcite and dolomite.

\begin{tabular}{lccccccc}
\hline \multicolumn{1}{c}{ No. } & A5-4 & A12-1 & A11-4 & A3-2 & A4-5 & A9-2 & A2-1 \\
\hline $\mathrm{MgO}$ & 02.87 & 02.41 & 03.39 & 02.39 & 00.06 & 01.89 & 00.07 \\
$\mathrm{CaO}$ & 51.50 & 51.92 & 50.27 & 51.68 & 54.30 & 52.30 & 53.36 \\
$\mathrm{FeO}$ & 00.16 & 00.17 & 00.21 & 00.15 & 00.04 & 00.05 & 00.00 \\
$\mathrm{MnO}$ & 00.03 & 00.06 & 00.06 & 00.06 & 00.10 & 00.00 & 00.06 \\
\hline $\mathrm{Total}$ & 54.55 & 54.56 & 53.93 & 54.28 & 54.50 & 54.24 & 53.63 \\
\hline $\mathrm{T}\left({ }^{0} \mathrm{C}\right)$ & 593 & 562 & 628 & 561 & 197 & 521 & 201 \\
\hline $\mathrm{MgCO}_{3}$ & 05.86 & 04.92 & 06.11 & 04.87 & 00.13 & 03.85 & 00.14 \\
$\mathrm{CaCO}_{3}$ & 92.25 & 93.05 & 90.02 & 92.53 & 97.38 & 93.66 & 95.66 \\
$\mathrm{FeCO}_{3}$ & 00.25 & 00.26 & 00.34 & 00.24 & 00.07 & 00.07 & 00.00 \\
$\mathrm{MnCO}_{3}$ & 00.05 & 00.09 & 00.10 & 00.09 & 00.17 & 00.00 & 00.10 \\
\hline Total & 98.40 & 98.32 & 97.37 & 97.73 & 97.75 & 97.59 & 95.90 \\
\hline
\end{tabular}

Carbonates were calculated using the Bence and Albee 13 correction method

$\mathrm{T}\left({ }^{0} \mathrm{C}\right)$ : equilibrium temperature for co-existing calcite and dolomite, based on Rice.14 
(2) Mica

Chemical compositions of mica from Sri Lanka (Table 7) and East Antarctica were plotted on a Phlogopite - Eastonite - Siderophyllite - Annite diagram (Figure 3). Mica in impure marble and skarn of Sri Lanka and most of the mica from skarn of Lutzow Holm Bay are rich in $\mathrm{Mg}$. The Sri Lankan phlogopite has a relatively higher silica content than Antarctica specimens.

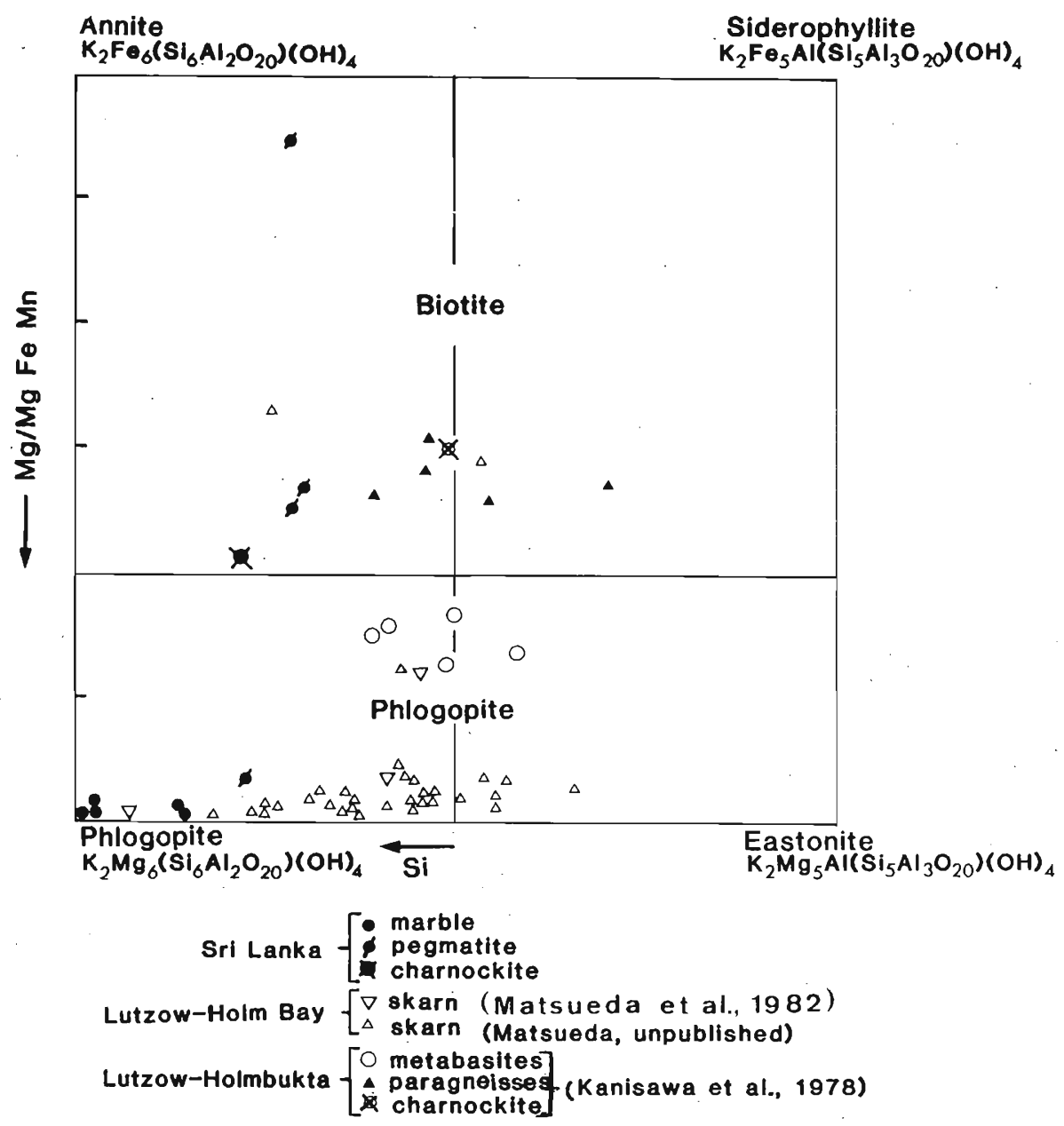

Figure 3: Chemical compositions of pyroxenes from Sri Lanka and Antarctica. 
Table 7: Chemical composition of mica (Sri Lanka) by EPMA.

\begin{tabular}{|c|c|c|c|c|c|c|c|c|}
\hline No. & $11 \mathrm{~A}$ & $11 \mathrm{~B}$ & $11 \mathrm{C}$ & 17 & 9 & $10 \mathrm{~A}$ & $10 \mathrm{~B}$ & $10 \mathrm{~B}$ \\
\hline $\mathrm{SiO}_{2}$ & 42.76 & 40.56 & 40.86 & 37.69 & 42.63 & 41.98 & 42.87 & 41.78 \\
\hline $\mathrm{FeO}$ & 01.26 & 00.38 & 03.64 & 14.26 & 00.22 & 00.37 & 00.39 & 00.75 \\
\hline $\mathrm{CaO}$ & 00.44 & 00.06 & 00.03 & 00.03 & 00.43 & 00.00 & 00.00 & 00.73 \\
\hline $\mathrm{Al}_{2} \mathrm{O}_{3}$ & 15.20 & 14.45 & 14.55 & 15.26 & 13.70 & 15.64 & 13.94 & 16.24 \\
\hline $\mathrm{MnO}$ & 00.06 & 00.00 & 00.01 & 00.02 & 00.00 & 00.10 & 00.01 & 00.08 \\
\hline $\mathrm{MgO}$ & 24.41 & 26.56 & 21.05 & 14.99 & 25.48 & 24.95 & 25.50 & 24.40 \\
\hline $\mathrm{TiO}^{2}$ & 00.27 & 00.18 & $04: 12$ & 02.27 & 01.30 & 00.96 & 00.20 & 00.14 \\
\hline $\mathrm{Na}_{2} \mathrm{O}$ & 00.21 & 00.80 & 01.07 & 00.15 & 00.95 & 01.51 & 01.12 & 00.59 \\
\hline $\mathrm{K}_{2} \mathrm{O}$ & 09.77 & 08.98 & 07.58 & 08.54 & 09.07 & 08.53 & 09.15 & 09.31 \\
\hline \multirow[t]{2}{*}{ Total } & 94.38 & 91.97 & 92.90 & 94.38 & 93.77 & 94.03 & 93.17 & 94.01 \\
\hline & \multicolumn{6}{|c|}{ Number of cations on the basis of $22(0)$} & & \\
\hline $\mathrm{Si}$ & 05.98 & 05.81 & 05.89 & 05.69 & 05.98 & 05.86 & 06.04 & 05.86 \\
\hline $\mathrm{Al}^{\mathrm{iv}}$ & 02.02 & 02.19 & 02.17 & 02.31 & 02.02 & 02.14 & 01.96 & 02.14 \\
\hline $\mathrm{Al}^{\mathrm{vi}}$ & 00.50 & 00.26 & 00.30 & 00.42 & 00.25 & 00.44 & 00.37 & 00.55 \\
\hline $\mathrm{Fe}$ & 00.15 & 00.05 & 00.43 & 01.80 & 00.03 & 00.04 & 00.05 & 00.09 \\
\hline $\mathrm{Ca}$ & 00.07 & 00.01 & 00.00 & 00.00 & 00.06 & 00.00 & 00.00 & 00.11 \\
\hline $\mathrm{Mn}$ & 00.01 & 00.00 & 00.00 & 00.00 & 00.00 & 00.01 & 00.00 & 00.01 \\
\hline $\mathrm{Mg}$ & 05.09 & 05.67 & 04.48 & 03.37 & 05.33 & 05.19 & 05.36 & 05.10 \\
\hline $\mathrm{Ti}$ & 00.03 & 00.02 & 00.44 & 00.26 & 00.14 & 00.10 & 00.02 & 00.01 \\
\hline $\mathrm{Na}$ & 00.06 & 00.22 & 00.30 & 00.04 & 00.26 & 00.41 & 00.31 & 00.16 \\
\hline $\mathrm{K}$ & 01.78 & 01.68 & 01.41 & 01.68 & 01.66 & 01.55 & 01.68 & 01.67 \\
\hline
\end{tabular}

17 if from charnockite (Massenna Estate, Balangoda).

(3) Pyroxene

Compositional similarity of pyroxenes in impure marble and skarn of Sri Lanka (Table 8) and East Antarctica was observed as shown in Figure 4. Clinopyroxenes occurred in skarn and impure marble from Sri Lanka are salite and diopside in composition, while cliropyroxenes from East Antarctica are salite, diopside and endiopside in composition.

(4) Amphibole

Amphiboles in skarn and impure marble of both Sri Lanka and East Antarctica is rich in Ca and belong to pargasite and paragasitic amphiboles in composition as shown in Table 8 and Figure 5. 


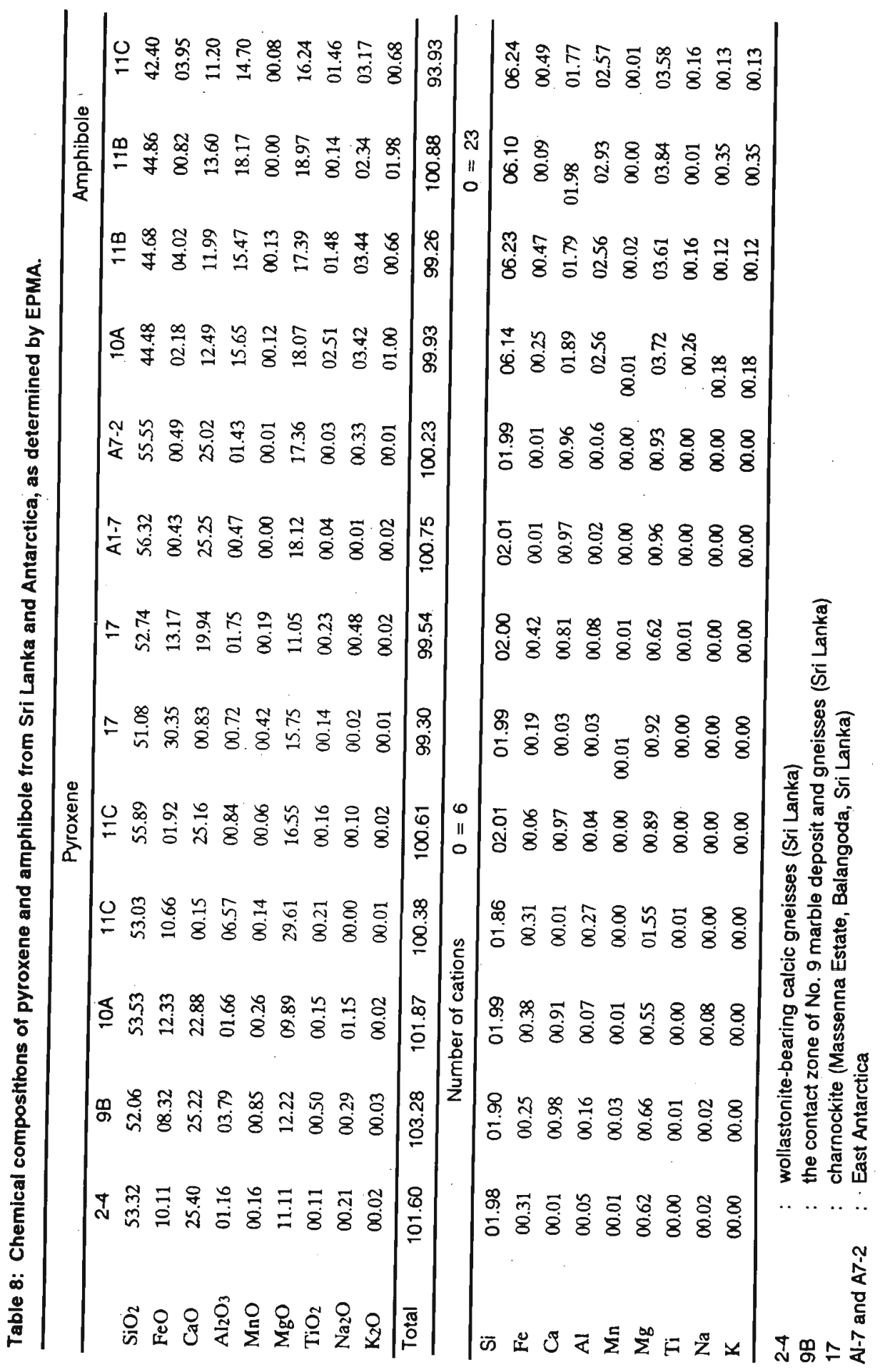




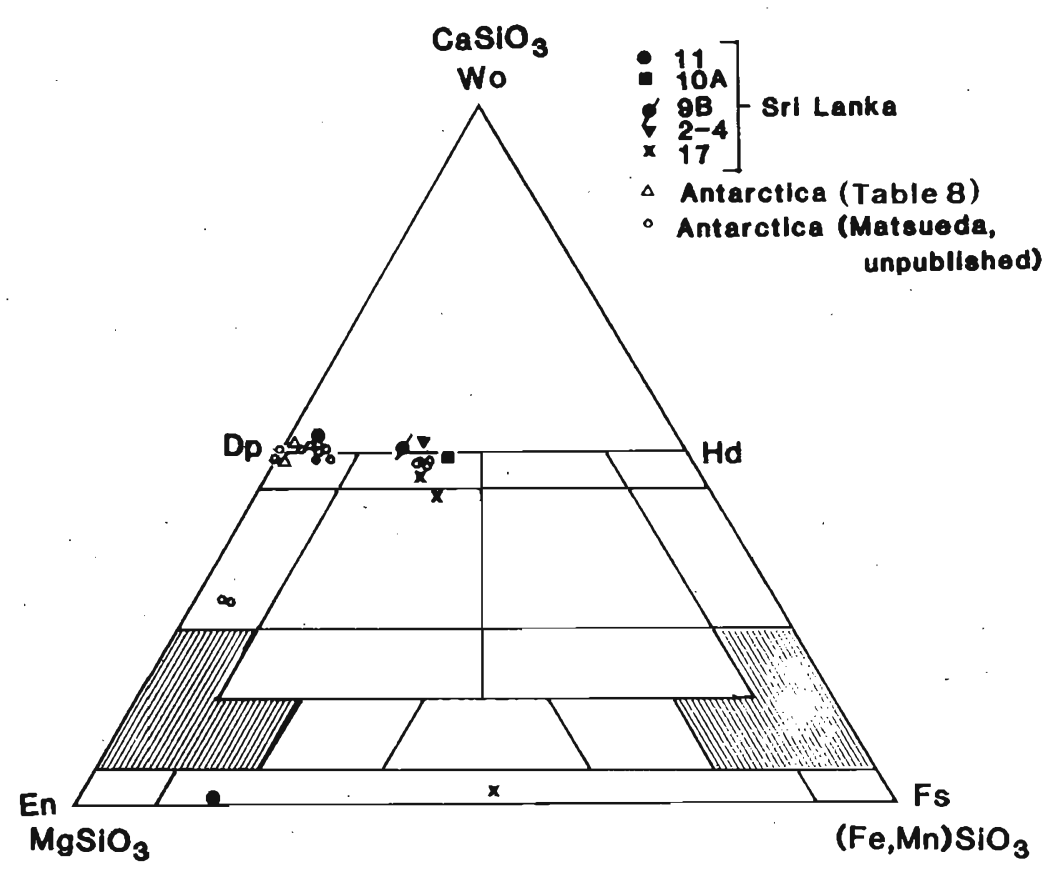

Figure 4: Chemical composition of pyroxenes from Sri Lanka and Antarctica, on the wollastonite (Wo) - ensiatite (En) - ferrosilite (Fs) diagram.

\section{(5) Graphite}

Sri Lanka is famous for highly pure (over $99 \%$ pure) vein type graphite, which is mined economically. Disseminated flaky graphite occurs in marble, skarn and gneisses both in Sri Lanka and East Antarctica.

Crystallinity of flaky graphite associated with samples mentioned above were checked by X-ray diffraction patterns. Results reveal crystallographically highly ordered graphite for both Sri Lanka and East Antarctica as shown in Fig. 6.

\section{(6) Apatite}

Light blue coloured apatite occur as an accessory mineral in marble and skarns of Sri Lanka and East Antarctica. X-ray diffraction patterns of these apatites are very similar to each other resemble carbonate - fluor and/or hydroxyl apatite.

\section{(7) Tourmaline}

Ca-rich tourmaline (Uvite), is a rare variety of tourmaline in nature and reported only from a limited number of localities. Uvite is abundant in Sri Lankan gem gravels. It 


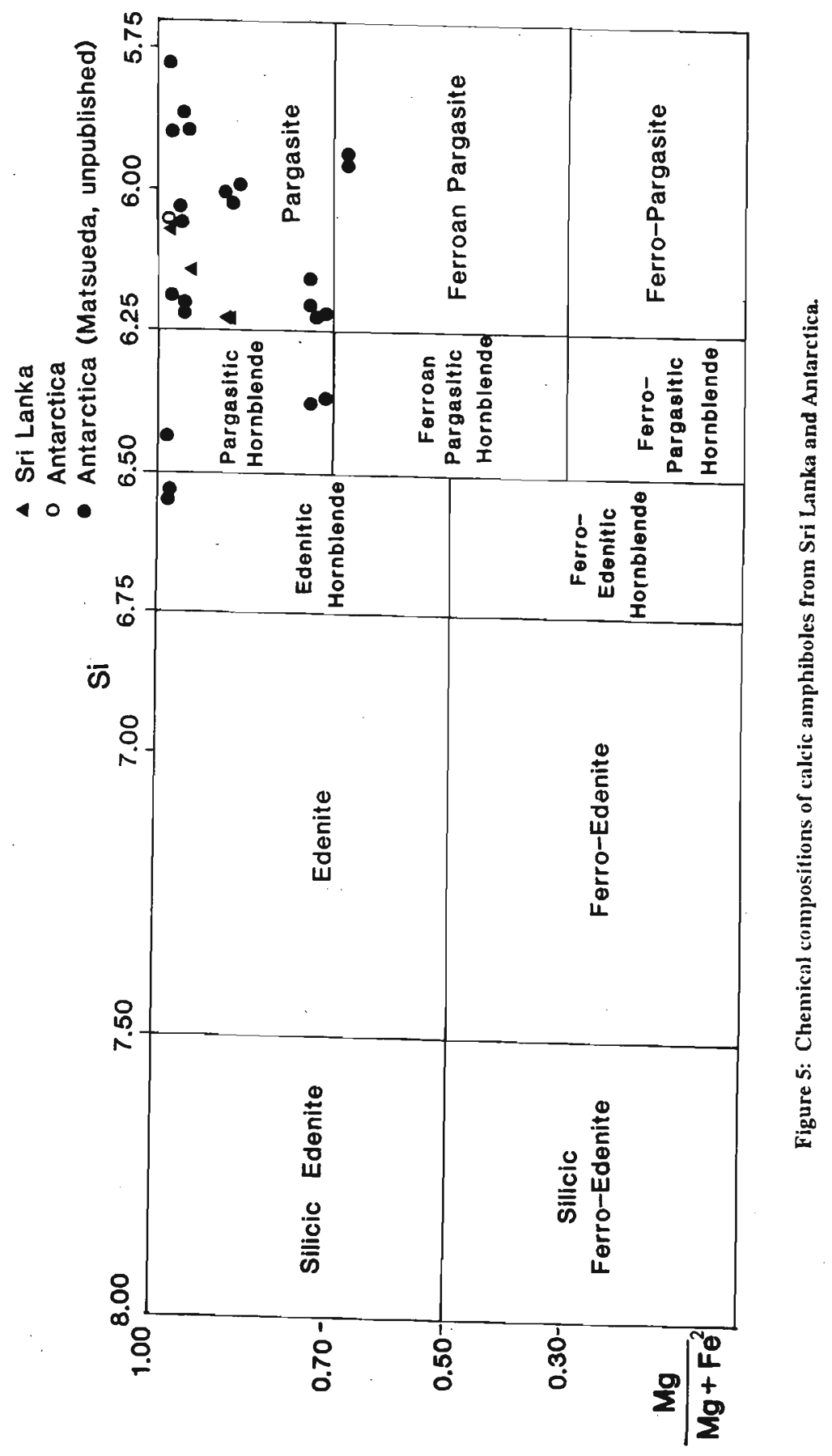




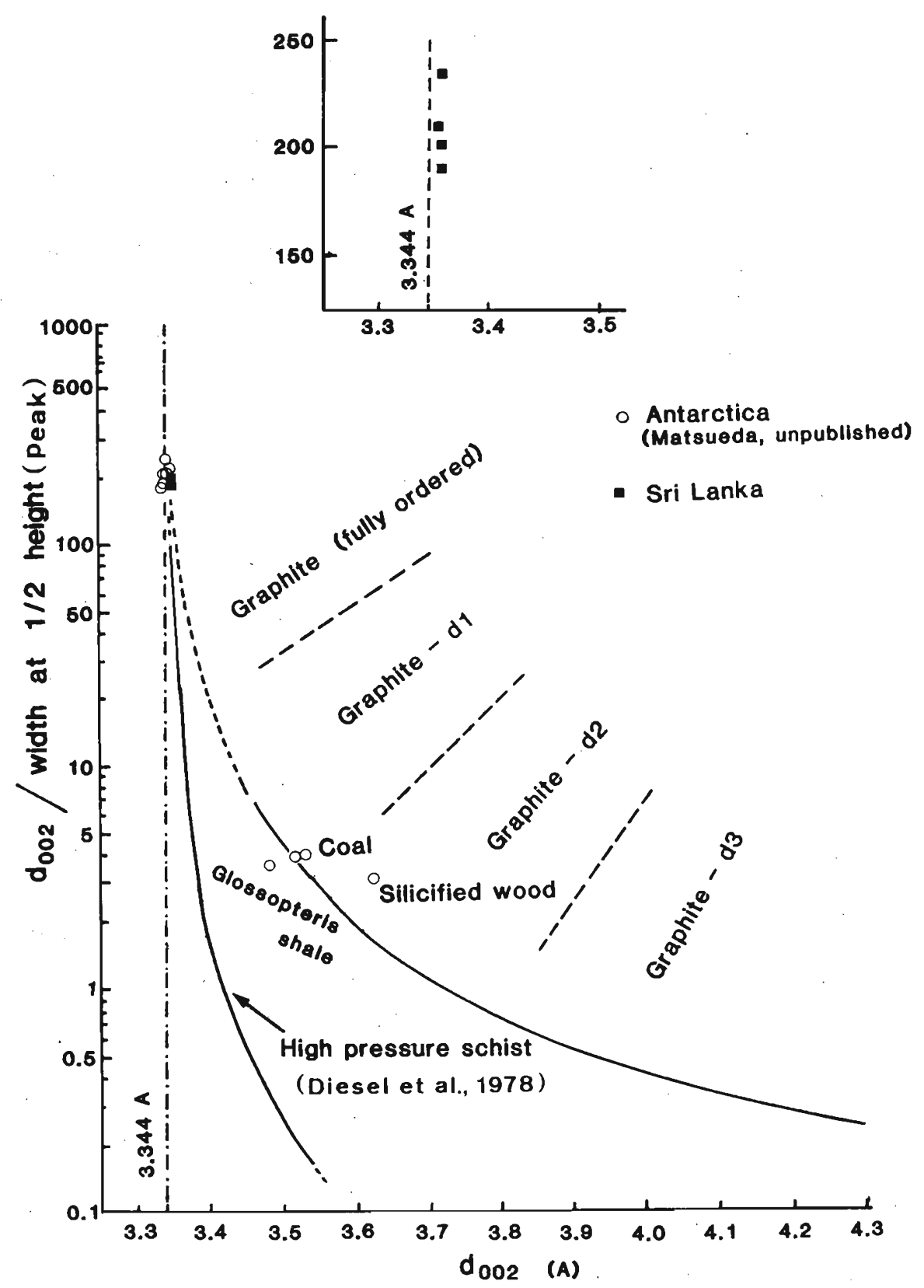

Figure 6: Order (dooz/width at 1/2 peak height) Vs dooz of graphite from Sri Lanka and Antarctica. The diagram is constructed on the basis of Landis ${ }^{27}$ and Diesel et al. ${ }^{28}$ 
occurs also in nodule-like skarn (pargasite - spinel - calcite - phlogopite skarn) at Ampitiya, Sri Lanka (Plate 1 (b)). A similar variety of tourmaline is observed in nodule-like skarn (phlogopite - analcime - amphibole - spinel etc.) on the east coast of Lutzow Holm Bay. ${ }^{3}$ Chemical analyses of these tourmalines are shown in Table 9.

Table 9: Chemical composition of tourmaline from Sri Lanka and Antarctica determined by EPMA.

\begin{tabular}{|c|c|c|c|c|c|c|}
\hline No. & $\mathrm{T} 1$ & $\mathrm{~T} 2$ & $\mathrm{~T} 3$ & 11 & $8-2$ & $70 t$ \\
\hline $\mathrm{SiO}_{2}$ & 38.76 & 38.87 & 38.75 & 38.92 & 37.31 & 36.37 \\
\hline $\mathrm{FeO}$ & 00.21 & 00.82 & 00.47 & 01.36 & 14.96 & 00.73 \\
\hline $\mathrm{CaO}$ & 04.50 & 03.82 & 04.24 & 03.64 & 00.24 & 03.23 \\
\hline $\mathrm{Al}_{2} \mathrm{O}_{3}$ & 29.26 & 30.35 & 29.38 & 31.08 & 32.12 & 27.00 \\
\hline $\mathrm{MnO}$ & 00.04 & 00.00 & 00.00 & 00.00 & 00.10 & 00.00 \\
\hline $\mathrm{MgO}$ & 13.75 & 12.52 & 10.03 & 12.19 & 02.08 & 12.27 \\
\hline $\mathrm{TiO}_{2}$ & 00.71 & 00.63 & 00.34 & 00.34 & 00.45 & 00.93 \\
\hline $\mathrm{Na}_{2} \mathrm{O}$ & 00.72 & 01.01 & 00.81 & 01.29 & 01.95 & 01.21 \\
\hline $\mathrm{K}_{2} \mathrm{O}$ & 00.03 & 00.02 & 00.10 & 00.03 & 00.06 & 00.01 \\
\hline $\mathrm{B}_{2} \mathrm{O}_{3}$ & (11.23) & $(11.26)$ & $(11.22)$ & (11.27) & (10.81) & (10.54) \\
\hline $\mathrm{H}_{2} \mathrm{O}$ & $(04.39)$ & $(04.47)$ & $(04.78)$ & $(04.23)$ & $(04.45)$ & $(04.57)$ \\
\hline Total & 103.60 & 103.76 & 103.16 & 10.4 .36 & 104.52 & 96.86 \\
\hline \multicolumn{7}{|c|}{ Number of cations of the basis of $31(0,0 \mathrm{H})$ from nomalized wt $\%$} \\
\hline $\mathrm{Si}$ & 06.00 & 06.00 & 06.00 & 06.00 & 06.00 & 06.00 \\
\hline $\mathrm{Fe}$ & 00.03 & 00.11 & 00.06 & 00.17 & 02.01 & 00.01 \\
\hline $\mathrm{Ca}$ & 00.75 & -00.63 & 00.70 & 00.60 & 00.04 & 00.57 \\
\hline $\mathrm{Al}$ & 05.37 & 05.55 & 05.39 & 05.68 & 06.12 & 05.28 \\
\hline $\mathrm{Mn}$ & 00.01 & 00.00 & 00.0 & 00.00 & 00.01 & 00.00 \\
\hline $\mathrm{Mg}$ & 03.17 & 02.88 & 03.01 & 02.80 & 00.50 & 03.02 \\
\hline $\mathrm{Ti}$ & 00.08 & 00.07 & 00.04 & 00.04 & 00.05 & 00.12 \\
\hline $\mathrm{Na}$ & 00.21 & 00.30 & 00.24 & 00.39 & 00.61 & 00.39 \\
\hline $\mathrm{K}$ & 00.01 & 00.00 & 00.01 & 00.01 & 00.01 & 00.00 \\
\hline B & 03.01 & 03.01 & 03.01 & 03.01 & 03.01 & 03.01 \\
\hline $\mathrm{OH}$ & 04.54 & 04.60 & 04.93 & 04.35 & 04.78 & 05.03 \\
\hline
\end{tabular}

$\mathrm{B}_{2} \mathrm{O}_{3}$ and $\mathrm{H}_{2} \mathrm{O}$ were calculated using ideal formula $(\mathrm{Si}=6, \mathrm{~B}=3$ ).

T1, T2, T3 - Jewels from gem pits, Sri Lanka.

11 - Green tourmaline crystal from sample no. 11, Sri Lanka.

8-2 - Black tourmaline crystal from topas pegmatite, Rattota, Sri Lanka.

70t - Antarctica tourmaline. ${ }^{3}$ 


\section{(8) Gamet}

Sri Lankan garnets in gem gravels and charnockite (from Balangoda) were analysed by EPMA (Table 10) and compared with garnets in pelitic gneisses (garnet - biotite gneisses and garnet - sillimanite gneisses) from Lutzow Holm Bay and in garnet sillimanite rocks from Mt.Riiser-Larsen of the Napier Complex in East Antarctica. Garnets from Sri Lankan gem gravel are relatively rich in pyrope component (up to $59 \%$ ) and correspond to granulite facies, while garnet in charnockite is rich in almandine and corresponds to granulite facies and amphibolite facies as shown in Figure 7. The metamorphic temperature calculated using $\mathrm{Mg}-\mathrm{Fe}$ partition between co-existing garnet and biotite in charnockite from Sri Lanka is around $572 \pm 30^{\circ} \mathrm{C}$. Garnets from Mt. Riiser Larsen and some of the garnets from Lutzow Holm Bay are rich in pyrope, while some are rich in almandine component (Figure 7). But all the garnets correspond to granulite facies as shown in Figure 7. Garnet from the Antarctic localities mentioned and those from Sri Lanka have thus crystalized under similar metamorphic conditions. The presence of high percentage of $\mathrm{MgO}$ in the pyralspite garnet in Sri Lankan gem gravel reveals the high pressure condition of their original rocks.

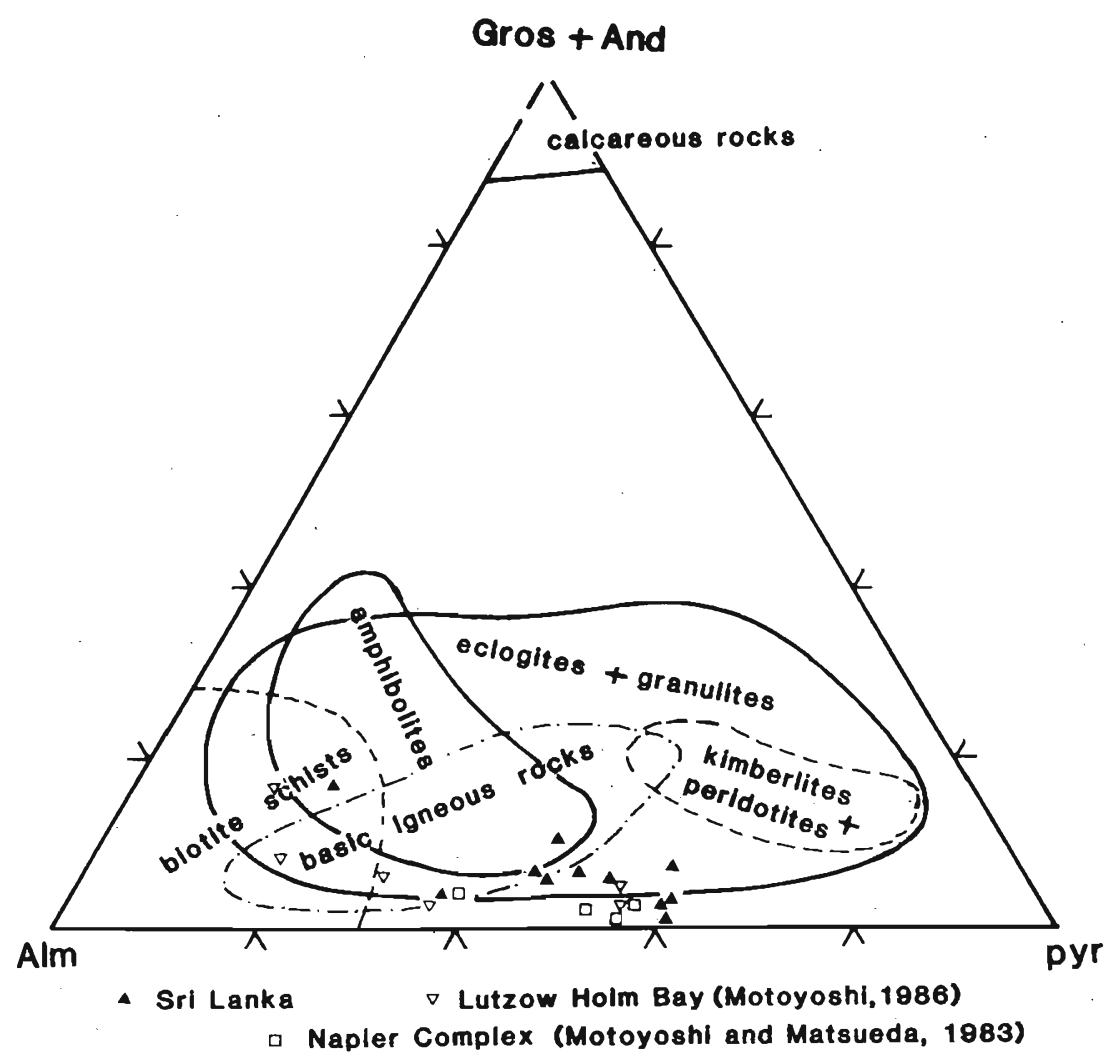

Figure 7: The limits of composition of garnet from various rock types and chemical composition of garnets from Sri Lanka and Antarctica on grossular + andradite (Gross + And) almandine (Alm) - pyrope (Pyr) diagram. 
Table 10 : Chemical compostion of garnet from Sri Lanka as determined by EPMA.

\begin{tabular}{|c|c|c|c|c|c|c|c|}
\hline No. & G1 & G2 & R4 & R8 & R9 & 17D & 17 \\
\hline $\mathrm{SiO}_{2}$ & 38.95 & 41.04 & 41.59 & 39.96 & 39.40 & 39.46 & 38.74 \\
\hline $\mathrm{FeO}$ & 27.18 & 18.60 & 23.80 & 18.12 & 03.04 & 10.43 & 27.44 \\
\hline $\mathrm{CaO}$ & 01.44 & 01.97 & 02.40 & 01.32 & 36.79 & 34.34 & 05.65 \\
\hline $\mathrm{Al}_{2} \mathrm{O}_{3}$ & 22.86 & 23.45 & 20.28 & 23.50 & 19.94 & 15.79 & 21.31 \\
\hline $\mathrm{MnO}$ & 00.66 & 02.25 & 00.40 & 00.31 & 00.18 & 00.13 & 01.54 \\
\hline $\mathrm{MgO}$ & 09.28 & 13.23 & 11.53 & 16.60 & 00.19 & 00.16 & 05.20 \\
\hline Total & 100.37 & 100.53 & 99.99 & 99.81 & 99.55 & 100.96 & 99.72 \\
\hline \multicolumn{8}{|c|}{ Number of cations of the basis of $24(0)$} \\
\hline $\mathrm{Si}$. & 05.95 & 06.05 & 06.28 & 05.88 & 06.04 & 06.02 & 06.05 \\
\hline $\mathrm{Al}^{\mathrm{iv}}$ & 00.05 & 00.00 & 00.00 & 000.12 & 00.00 & 00.00 & 00.00 \\
\hline $\mathrm{Al}^{\mathrm{vi}}$ & 04.10 & 04.09 & 03.90 & 03.98 & 03.63 & 02.94 & 03.96 \\
\hline $\mathrm{Fe}$ & 03.48 & 02.29 & 03.00 & 02.23 & 00.39 & 01.37 & 03.60 \\
\hline $\mathrm{Ca}$ & 00.24 & 00.31 & 00.39 & 00.21 & 06.05 & 05.78 & 00.95 \\
\hline $\mathrm{Mn}$ & 00.09 & 00.28 & 00.05 & 00.04 & 00.02 & 00.02 & 00.20 \\
\hline $\mathrm{Mg}$ & 02.11 & 02.91 & 02.59 & 03.64 & 00.04 & 00.04 & 01.22 \\
\hline $\mathrm{X}_{\mathrm{Mg}}$ & 00.37 & 00.56 & 00.46 & 00.62 & 00.09 & 00.02 & 00.25 \\
\hline \multicolumn{8}{|c|}{ Mole $\%$ end members } \\
\hline Alm. & 58.79 & 39.59 & 47.96 & 36.43 & 00.40 & 06.87 & 60.16 \\
\hline And. & 00.00 & 00.00 & 05.37 & 00.03 & 08.93 & 22.50 & 00.50 \\
\hline Gros. & 03.99 & 05.37 & 01.29 & 03.37 & 89.58 & 69.75 & 15.46 \\
\hline Pyr. & 35.78 & 50.19 & 44.50 & $59: 53$ & 00.71 & 00.60 & 20.44 \\
\hline Spes. & 01.45 & 04.85 & 00.88 & 00.63 & 00.38 & 00.28 & 03.44 \\
\hline
\end{tabular}

G1, G2, R4, R8, R9 - Jewels from Sri Lankan gem gravel.

17D - Garnet associating with calcite (Massanna estate, Balangoda).

17 - Garnet in charnockite (Massanna estate, Balandoda).

Colours: - Based on the colour tone manual

G1 - vivid red, G2 - strong red purple, R4 - vivid red, R8 - purplish pink, R9 - vivid reddish orange.

\section{(9) Spinel}

Deep blue coloured spinel, so called Ceylonite, is one gem variety of spinel in Sri Lanka. Up to $18 \mathrm{wt} \%$ of $\mathrm{ZnO}$ content in some of these spinels has been reported from Sri Lanka. ${ }^{15}$ A similar variety of spinels ( $\mathrm{ZnO}$ up to $\left.18.05 \mathrm{wt} \%\right)$ is found also in skarn of the east coast of Lutzow Holm Bay. ${ }^{3}$ Table 11 shows the chemical 
composition of Sri Lankan spinels which were derived from gem gravel, impure marble and skarn deposits.

Table 11 : Chemical composition of spinel (Sri Lanka) by EPMA.

\begin{tabular}{|c|c|c|c|c|c|c|c|}
\hline No. & \$1 & S3 & S4 & $11 \mathrm{~B}$ & 10 & $11 \mathrm{D}$ & $11 \mathrm{~B}$ \\
\hline $\mathrm{Al}_{2} \mathrm{O}_{3}$ & 71.79 & 71.98 & 71.34 & 71.99 & 72.21 & 68.21 & 67.79 \\
\hline $\mathrm{MgO}$ & 26.57 & 27.46 & 27.59 & 25.97 & 26.00 & 16.58 & 21.70 \\
\hline $\mathrm{FeO}$ & 02.44 & 01.24 & 00.92 & 02.47 & 01.73 & 15.81 & 02.37 \\
\hline $\mathrm{SiO}_{2}$ & 00.00 & 00.00 & 00.03 & 00.01 & 00.04 & 00.02 & 00.00 \\
\hline $\mathrm{TiO}_{2}$ & 00.00 & 00.00 & 00.00 & 00.00 & 00.00 & 00.02 & 00.00 \\
\hline $\mathrm{ZnO}$ & - & - & - & - & - & - & 08.00 \\
\hline $\mathrm{Cr}_{2} \mathrm{O}_{3}$ & 00.00 & 00.00 & 00.00 & 00.00 & 00.00 & - & $\therefore$ \\
\hline Total & 100.80 & 100.68 & 99.88 & 100.44 & 99.99 & 100.70 & 99.86 \\
\hline \multicolumn{8}{|c|}{ Number of cations on the basis of $32(0)$} \\
\hline $\mathrm{Al}$ & 16.14 & 16.12 & 16.09 & 16.24 & 16.30 & 16.23 & 15.98 \\
\hline $\mathrm{Mg}$ & 07.52 & 07.74 & 07.83 & 07.37 & 07.38 & 04.98 & 06.46 \\
\hline $\mathrm{Fe}$ & 00.39 & 00.20 & 00.15 & 00.39 & 00.28 & 02.67 & 00.40 \\
\hline $\mathrm{Si}$ & 00.00 & 00.00 & 00.01 & 00.00 & 00.01 & 00.00 & 00.00 \\
\hline $\mathrm{Ti}$ & 00.00 & 00.00 & 00.00 & 00.00 & 00.00 & 00.00 & 00.00 \\
\hline $\mathrm{Cr}$ & 00.00 & 00.00 & 00.00 & 00.00 & 00.00 & - & - \\
\hline $\mathrm{Zn}$ & - & - & - & - & - & - & 01.18 \\
\hline
\end{tabular}

S1, S3, S4 : Jewels

Colours : (based on colour tone manual)

S1 - deep greenish blue,

S3 - soft purplish blue,

S4 - bright violet

11B, 11D : From sample No 11 B and 11D Colour : blue

10 : From sample No. $10 \quad$ Colour : pink

\section{(10) Conundum}

Corundum is a significant mineral in Sri Lankan gem gravels. Large amount of blue coloured corundum also have been discovered in phlogopite-bearing skarn and gneisses associated with marble around Lutzow Holm Bay and Prince Olav Coast by Japanese Antarctic research expedition groups. Some of the Sri Lankan corundum crystals examined are associated with phlogopite. Therefore, the genesis of these corundums might be similar to those found in Antarctica. 


\section{(11) Sapphirine}

Sapphirine is associated with spinel and phlogopite or enstatite (bronzite), kornerupine, in skarn at Ampitiya (sample No. 11C). Pyrite is a common accessory mineral (crystals up to $3 \mathrm{~cm}$ in diameter) and a $\mathrm{TiO}_{2}$ phase (probably rutile) is also present as an accessory. Sapphirine seems to be concentrated in layers in association with phlogopite (Plate 2(a)). EPMA data of Sri Lanka Sapphirines are given in Table 12. The plots of these data together with the data obtained from sapphirines from Lutzow Holm Bay and from the Napier Complex (Figure 8) show that sapphirines from each of the three localities have distinctive compositions. This could be due to compositional differences in the original sediments or differences in the diffusibility during the formation of sapphirine. Sapphirine from the Napier Complex (Mt. Riiser Larsen) is associated with comparatively high grade minerals like osumilite, whereas Sri Lankan sapphirine is associated with lower grade minerals such as phlogopite. The sapphirine-quartz assemblage is well developed in the Napier Complex but it is very rare in Sri Lankan samples (Plate 2(b)). Occurrence of sapphirine in direct contact with quartz in Sri Lanka has not been previously reported and leads one to consider the possibility of high grade metamorphism at the temperatures exceeding $900 \pm 30^{\circ} \mathrm{C}$ and pressures of $7 \pm 1 \mathrm{Kbar}$, as suggested by Grew, ${ }^{16}$ or over $800^{\circ} \mathrm{C}$ according to Newton, ${ }^{17}$ for sapphirine plus quartz in the Napier Complex. Enstatite

Table 12: Chemical composition of sapphirine from sample No. $11 \mathrm{C}$ determined by EPMA.

\begin{tabular}{|c|c|c|c|c|}
\hline Analysis No. & 1 & 2 & 3 & 4 \\
\hline $\mathrm{SiO}_{2}$ & 14.27 & 15.30 & 14.72 & 14.67 \\
\hline $\mathrm{Al}_{2} \mathrm{O}_{3}$ & 63.51 & 60.74 & 58.55 & 60.68 \\
\hline $\mathrm{FeO}$ & 03.78 & 04.14 & 05.74 & 04.58 \\
\hline $\mathrm{MnO}$ & 18.94 & 18.74 & 19.09 & 18.78 \\
\hline $\mathrm{CaO}$ & 00.03 & 00.18 & 00.00 & 00.00 \\
\hline $\mathrm{Na}_{2} \mathrm{O}$ & 00.00 & 00.02 & 00.00 & 00.00 \\
\hline Total & 100.59 & 99.20 & 98.14 & 98.73 \\
\hline \multicolumn{5}{|c|}{ Number of cations on the basis of $20(0)$} \\
\hline $\mathrm{Si}$ & 01.66 & 01.80 & 01.77 & 01.74 \\
\hline $\mathrm{Al}^{\mathrm{iv}}$ & 04.34 & 04.20 & 04.23 & 04.26 \\
\hline $\mathrm{Al}^{\mathrm{vi}}$ & 04.39 & 04.29 & 04.12 & 04.28 \\
\hline $\mathrm{Fe}$ & 00.37 & 00.41 & 00.58 & 00.45 \\
\hline $\mathrm{Mn}$ & 00.01 & 00.01 & 00.00 & 00.00 \\
\hline $\mathrm{Mg}$ & 03.28 & 03.29 & 03.42 & 03.32 \\
\hline $\mathrm{Ca}$ & 00.00 & 00.02 & 00.00 & 00.00 \\
\hline $\mathrm{Na}$ & 00.00 & 00.00 & 00.00 & 00.00 \\
\hline
\end{tabular}



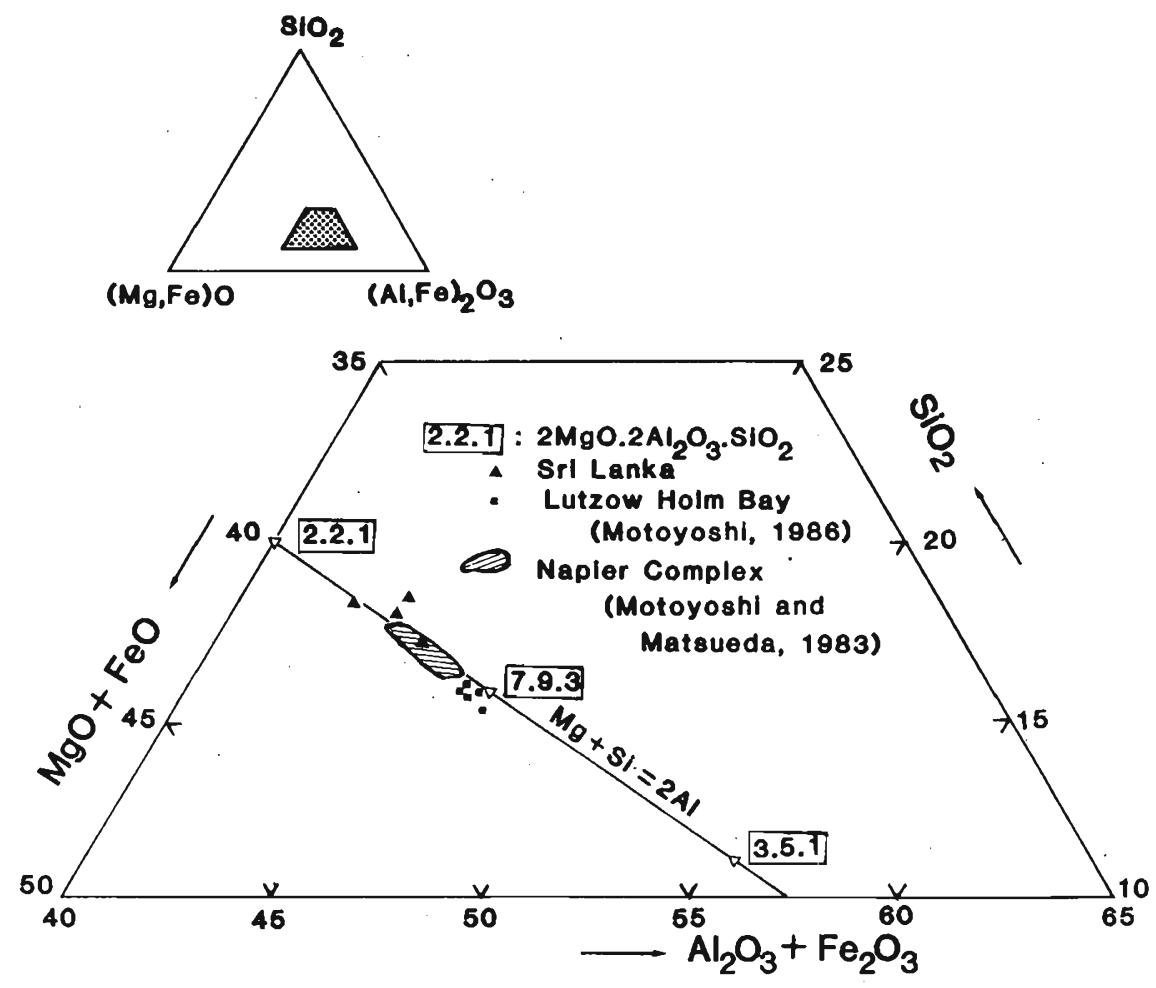

Figure 8: Chemical composition of sapphirine from Sri Lanka and Antarctica on the $\mathrm{SiO}_{2} \cdot(\mathrm{MgO}+$ $\mathrm{FeO}) \cdot\left(\mathrm{Al}_{2} \mathrm{O}_{3}+\mathrm{Fe}_{2} \mathrm{O}_{3}\right)$ diagram.

associated with sapphirine in Sri Lanka is rich in $\mathrm{FeO}$ (up to $10.66 \mathrm{wt} \%$, Table 8) and could be regarded as bronzite. Enstatite is also rich in $\mathrm{Al}_{2} \mathrm{O}_{3}$ (up to 6.74 wt \%) and this is further evidence for high grade metamorphism because $\mathrm{Al}_{2} \mathrm{O}_{3}$ in enstatite (pyroxene) increases with the grade of metamorphism. ${ }^{18,19}$ Plate 2 (c) shows the association of sapphirine with kornerupine and enstatite.

(12) Others

Feldspar in pegmatite deposits shows well developed microcline perthitic or antiperthitic texture where some of those occur as moonstone in Sri Lanka and as amazonite in Antarctica. 
(a)

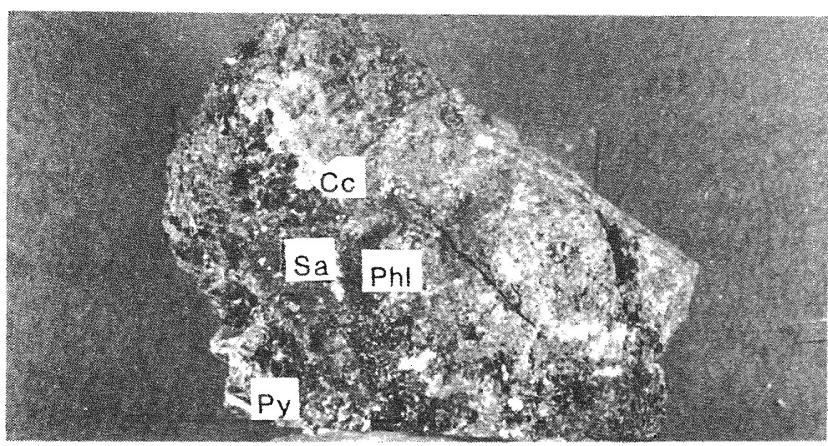

(b)

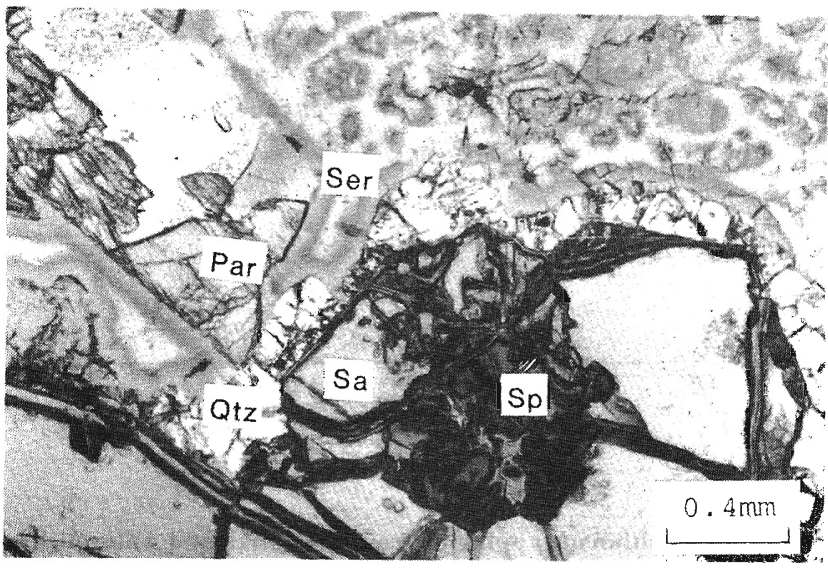

(c)

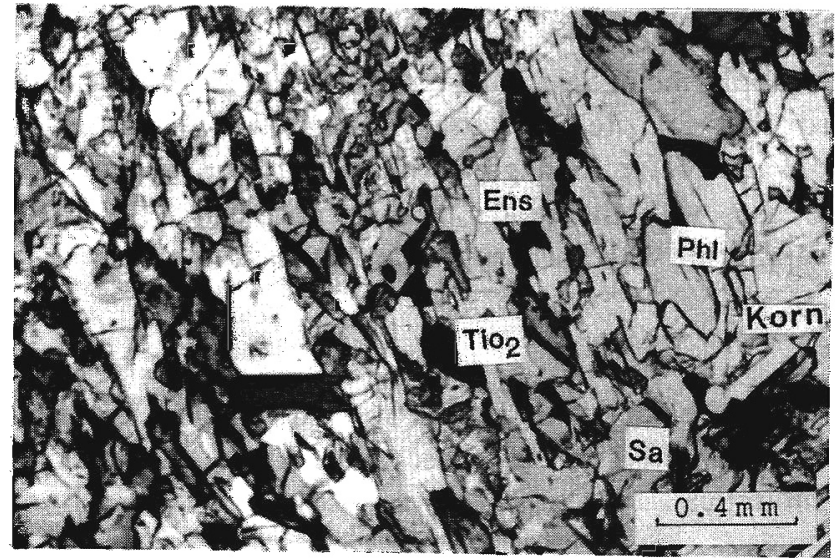

Plate 2: (a) Sapphirine bearing sample from Sri Lanka (Ampitiya, Kandy) showing the concentration of sapphirine with phlogopite. Sa: sapphirine, Phl: phlogopite, Cc: calcite, Py: pyrite.

(b) Sapphirine-quartz assemblage under the microscope (parallel nicols) from Sri Lanka (Ampitiya, Kandy). Sa: sapphirine, Qtz: quartz, Sp: spinel, Par: pargasile, Ser: serpentine.

(c) Sapphirine (Sa) - enstatite (Ens) - kornerupine (Korn) - phlogopite assemblage under the microscope (parallel nicols) from Sri Lanka (Ampitiya, Kandy). 


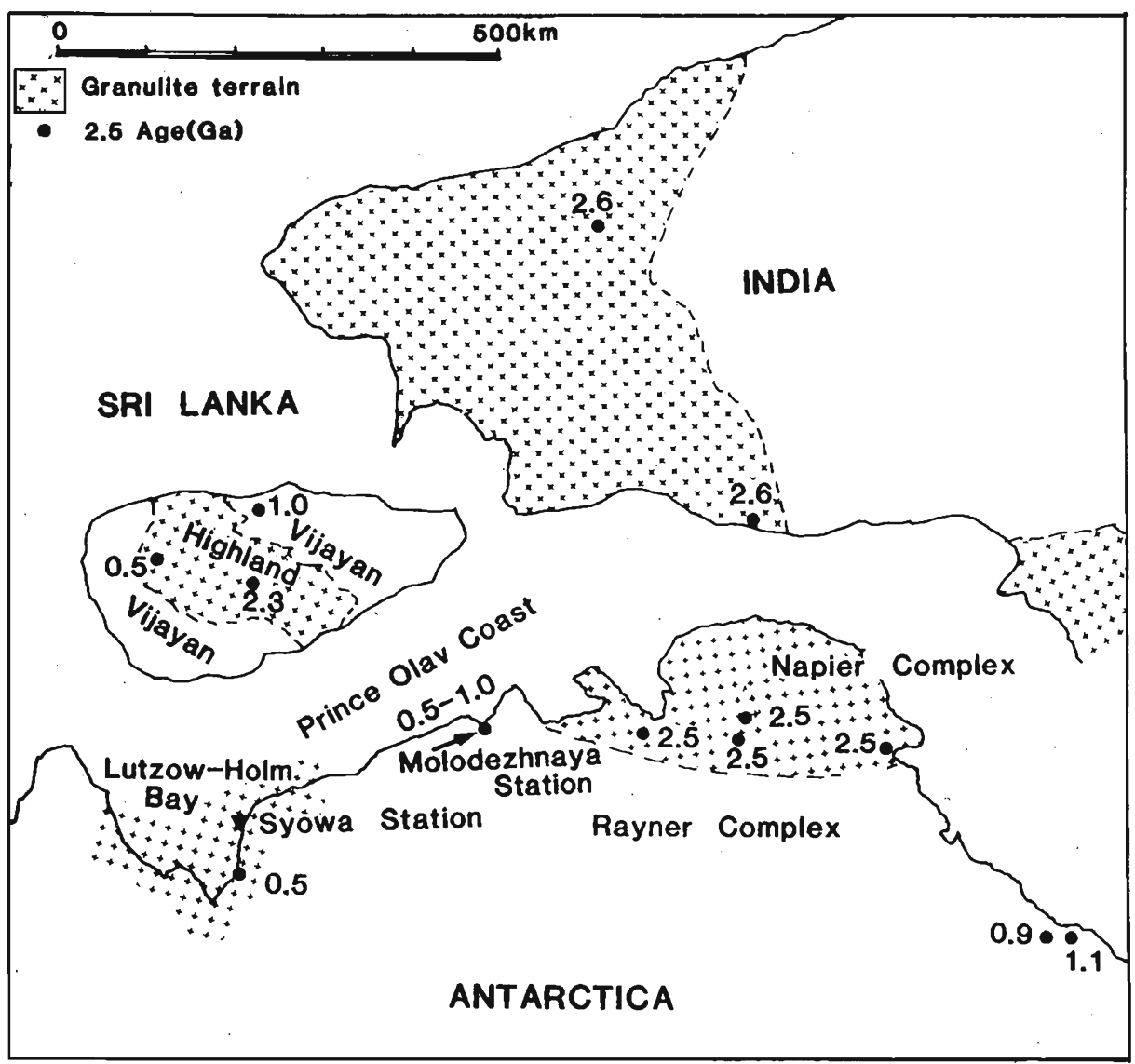

Figure 9: Reconstruction of Gondwanaland around Lutzow Holm Bay, Prince Olav Coast and Napier Complex showing the distribution of granulites and geochronological data.,11

Beryl (aquamarine)is present in pegamatites in both Sri Lanka and East Antarctica (K. Yanai, personal communication).

Staurolite is also present as inclusions in garnets in Sri Lanka (Y. Hiroi, pers. commun.) and in East Antarctica. ${ }^{20}$

\section{DISCUSSION}

In Sri Lanka, Highland/Southwestern Complex rocks are characterized by mineralogy of relatively high metamorphic grade (granulite facies), while rocks of the Vijayan 
Complex and Wanni Complex are characterised by hornblende and biotite. Pegmatite occurs in the Highland/Southwestern Complex, Vijayan Complex and Wanni Complex but migmatite is not found in the Highland/Southwestern Complex.

Rocks in the Lutzow Holm Complex (Lutzow Holm Bay and Prince Olav Coast) of East Antarctica are well-layered gneisses, migmatitic rocks, granite and pegmatite. The well-layered gneisses are subdivided into pelitic and psammitic, basic to intermediate, ultra basic, calcareous and quartzitic varieties. ${ }^{21}$ Pelitic garnet-silimanite gneisses, which are characterized by huge crystals of garnets, in Lutzow Holm Bay region, are similar to kondalites in Highland Series of Sri Lanka. Lutzow Holm Complex is characterized by the progressive metamorphism from east to west. ${ }^{11}$ Migmatitic rocks, granite and pegmatite are abundunt in the Prince Olav Coast rather than in the Lutzow Holm Bay region. ${ }^{21}$

In general, metamorphic facies and rock lithologies in Sri Lanka and Lutzow Holm Bay are quite similar. According to Hapuarachchi ${ }^{5}$ the metamorphic temperature of the granulite facies in Sri Lanka ranges from $700^{\circ}$ to $840^{\circ} \mathrm{C}$. Motoyoshi ${ }^{22}$ estimated the minimum P-t conditions for the Lutzow Holm Bay region as $850{ }^{\circ} \mathrm{C}$ and $8-9 \mathrm{k}$ bars. Jayawardana and Carswell ${ }^{23}$ considered the P-T conditions of metamorphism of charnockite and pyroxene granulites of South East Sri Lanka to be $700 \pm 50^{\circ} \mathrm{C}$ and $5-7.5 \mathrm{k}$ bars. This matches closely the P-T conditions of the Rayner Complex in the coastal region (at Molodezhnaya station) viz. $700 \pm 30^{\circ} \mathrm{C}$ and $5.5 \pm 1 \mathrm{k}$ bars, proposed by Grew. ${ }^{24}$

The sapphirine-quartz assemblage, which is well developed in the Napier Complex but not reported so far from Lutzow Holm Bay, occurs very rarely also in Sri Lankan samples studied. Sapphirine and quartz in direct contact in Sri Lanka suggests high P-T metamorphic conditions. The occurrence of lower grade minerals with Sri Lanka sapphirine could be due to retrograde metamorphism. This suggests that the P-T conditions in Sri Lanka may be closer to those in Lutzow Holm Bay rather than in Napier Complex.

A very similar mode of occurrence, paragenesis and compositional relationship of minerals were observed in impure marble and skarn deposits from Sri Lanka and East Antarctica. The presence of calcite-dolomite exsolution texture is a unique characteristic feature in these dolomitic marble and skarn deposits. The occurrence of various gem minerals such as corundum, spinerl, garnet, rare variety of tourmaline (uvite), etc. in both Sri Lanka and East Antarctica infers similar mineralogical conditions in both regions. This is supported by the very similar compositions of the gem minerals from these respective regions. Considering the nature of the general geology of the regions surrounding Ratnapura in Sri Lanka, the source rocks of the gem gravels could be skarn and gneisses associated with marble as in Lutzow Holm Bay in Antarctica. Figure 9 is a reconstruction of Gondawanaland around Lutzow 
Holm Bay, Prince Olave Coast and Napier Complex, showing the distribution of granulite facies terrain and of geochronological data. ${ }^{1,11}$ We conclude that the geology, mode of occurrence and mineralogy of marble and skarn deposits of Sri Lanka are similar overall to those of Lutzow Holm Bay and the Prince Olav Coast of . East Antarctica. This supports the attachment of Sri Lanka to the Lutzow Holm Bay and Prince Olav Coast region of East Antarcitca as part of a Gondwanaland reconstruction.

\section{Acknowledgements}

Authors are thankful to Drs K. Shiraishi and Y. Motoyoshi (National Institute of Polor Research), Y. Hiroi (Chiba University) and M. Yoshida (Osaka City University) for useful discussions and kind assistance. Authors are also thankful to Dr Robin L. Oliver for his critical comments on the paper. This work was partly supported by Grant-in-Aid of the Overseas Scientific Research Program No. 63041031 of the Ministry of Education, Science and Culture, Japan.

\section{References}

1. Grew E.S. \& Manton W.I., (1979). Archean rocks in Antarctica : 2.5 -billion year uranium-lead ages of pegmatites in Enderby land. Science 206: 443-445.

2. Cooray P.G., Abesinghe P.B. \& Pram, W.K.B.N., (1987). Precambrian geology of Sri Lanka, Geological Society of Sri Lanka; Special Publication No. 2, Peradeniya, pp. 9-19.

3. Matsueda H., Motoyoshi Y. \& Matsumoto Y., (1982). Mg-Al Skarn of the skallevikhalsen in the east coast of Lutzow-Holm bay, East Antarctica. Proceedings of the third symposium on Antarctica geosciences, pp. 166-176. National Institute of Polar Research, Japan,

4. Kroner A., Cooray P.G. \& Vitanage P.W., (1991). Lithotectonic subdivision of the precambrian basement in Sri Lanka. Professional paper, 5: 5-18. Geological Survey Department, Colombo.

5. Hapuarachchi D.J.A.C., (1975). The granulite facies in Sri Lanka, Geological Survey Department, Colombo.

6. Kroner A., Williams I.S., Compston W., Baur N., Vitanage P.W. \& Perera L.R.K., (1987). Zircon ion microprobe dating of high-grade rock in Sri Lanka. Joumal of Geology 95 : 775-791.

7. Cooray P.G., (1967). An Introduction to the Geology of Ceylon. National Museums of Ceylon Publication, Colombo, pp. 83-141. 
8. Voll G. \& Kleinschrodt R., (1991). Sri Lanka: Structural, magmatic and metamorphic development. Professional paper No. 5:22-50. Geological Survey Department, Colombo.

9. Herath J.W. (1980). Mineral resources of Sri Lanka. Geological Survey Department, Colombo, pp. 13-18.

10. Sheraton J.W., Offe L.A., Tingey R.J. \& Ellis D.J., (1980). Enderby Land, Antarctica - an unusual Precambrian high grade metamorphic terrain. Journal of the Geological Society 27: 1-18.

11. Hiroi Y., Shiraishi K., Motoyoshi Y., Kanisawa S. \& Yanai K., (1986). Mode of occurrence, Bulk chemical compositions, and Mineral textures of ultramafic rocks in the Lutzow Holm Complex, East Antarctica, Proceedings of the sixth symposium on Antarctica Geoscience, National Institute of Polar Research, Japan, pp. 62-84.

12. Banno S., Tatsumi T., Kuno H., \& Katsura T., (1964). Mineraloty of granulite facies rocks in the area around Lutzow-Holm Bay, Antarctica. Japanese Antartic Research Expedition Scientific Reports Series C (Geology) 1: 12p.

13. Bence, J.H. \& Albee, A.C., (1968). Empirical correction factors for the electron microanalysis of silicates and oxides. Joumal of Geology $76: 382-403$.

14. Rice J.M., (1977). Progressive metamorphism of impure dolomitic limestone in the Marysville Aureole, Montana. American Journal of Science 277: 1-24.

15. Anderson B.W. \& Payne J.C. (1937). Magnesium - Zinc - Spinel from Ceylon. Mineralogical Magazine xxiv: 547 - 554.

16. Grew E.S., (1980). Sapphirine + quartz association from Archean rocks in Enderby Land, Antarctica. American Mineralogist 65: 821-836.

17. Newton R.C. (1972). An experimental determination of the high-pressure stability limits of magnesium cordierite under wet and dry conditions. Journal of Geology 80: 398-420.

18. Anastasiou P. \& Seifert F., (1972). Solid solubility of $\mathrm{Al}_{2} \mathrm{O}_{3}$ in Enstatite at High Temperatures and 1-5 kb Water Pressure. Contributions to Minerology and Petrology 34: 272-287.

19. Baker F., (1964). Sapphire bearing rock, Val Codera, Italy. American Minerologist 49: 146-152.

20. Motoyoshi Y., Matsubara S., Matsueda H. \& Matsumoto Y., (1984). Garnet -sillimanite gneisses from the Lutzow-holm bay region, East Antarctica. 
Proceedings of the Fifth Symposium on Antarctica Geoscience, pp. 82-94. National Institute of Polar Research, Japan.

21. Shiraishi K., (1985). Geology and petrology of late proterozoic metamorphic complex in Eastern Queen Maud Land, East Antarctica Shield. Doctoral thesis Hokkaido University, Japan.

22. Motoyoshi Y., (1986). Prograde and progressive metamorphism of the granulite-facies Lutzow-Holm Bay region, East Antarctica. Doctoral thesis, Hokkaido University, Japan.

23. Jayawardana D.E. de S. \& Carswell D.A., (1976). The geochemistry of charnockites and their constituent ferromagnesian minerals from the Precambrian of South-East Sri Lanka (Ceylon). Minerological Magazine 40: 542-553.

24. Grew, E.S., (1981). Granulite - Facies Metamorphism at Molodezhnayam station, East Antarctica. Joumal of Petrology 22 Part 3: 297-336.

25. Motoyoshi Y. \& Matsueda H., (1983). Archean granulites from Mt. Riiser-larsen in Enderby land, East Antarctica. Proceedings of the fourth symposium on Antarctica Geoscience, pp. 103-125. National Institute of Polar Research, Japan.

26. Kanisawa S., Oniki H. \& Yanai K., (1978). Chemical characteristics of biotites and hornblende from metamorphic rocks around Lutzow-Holmbukta, East Antarctica. Proceedings of the first symposium on Antarctica Geoscience, pp. 153-163. National Institute of Polar Research, Japan.

27. Landis C.A., (1971). Graphitization of dispesred carbonaceous material in Metamorphic rocks. Contributions to Minerology and Petrology 30: 34-45.

28. Diesel C.F.K., Brothers R.N. \& Black P.M., (1978). Coalification and graphitization in high-pressure schists in New Caledonia. Contributions to Minerology and Petrology 68: 63-78. 